\title{
اختصاص مجلس الدولة في تدقيق مشروعات التشريعات
}

\section{“بحث مستل من اطروحة دكتوراه”}

\author{
م.P.مبهدين شهاب احمد، قسم القانون، جامعة نوروز ، أقليم كوردستان العراق

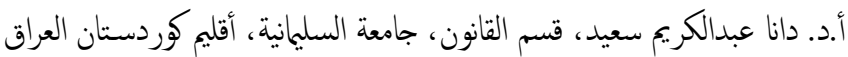

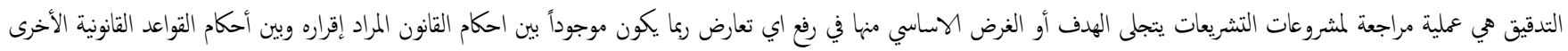

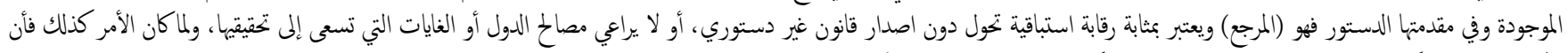

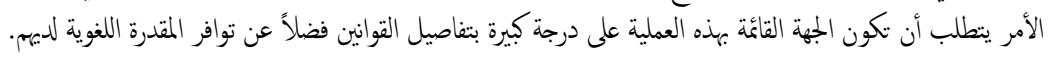

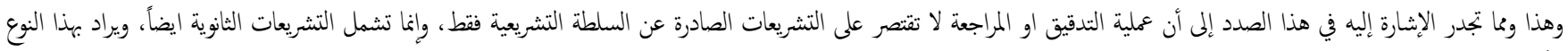

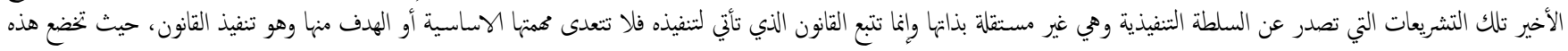
التشريعات الثانوية من قبل عدة بجات.

الكلمات المالة : الندقيق - المراجعة - مجلس الدولة.

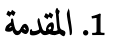

يعتبر التشريع الأداة التي يتم بواسطتها تطبيق السياسة العامة العليا في المجلات 2.1 مشكلة موضوع البحث

تدور اشكلية موضوع البحث حول ايجاد اجوبة مناسبة للتساؤلات التالية : ما المقصود بعملية تدقيق مشروعات القوانين .

ماهي المبادئ الاساسية التي تقوم عليها عملية تدقيق مشروعات القوانين .

هل يختص مجلس الدولة في العراق وفي الدول محل الدراسة بعملية تدقيق مشروعات القوانين · مش

\section{1}

اعتمدنا في كتابة البحث على المنهج التحليلي الذي يعول على تحليل النصوص الواردة في القوانين والتشريعات في الدول محل الدراسة بقصد بيان مدى اختصاص مجلس الدولة بعملية تدقيق مشروعات القوانين .

\section{1}

من المعلوم ان اختصاصات مجلس الدول كثبرة ومتنوعة ونخن في اطار هذا البحث سوف لن نتطرق الى جميع تلك الاختصاصات وانما سنشير فقط الى اختصاص مجلس الدولة في عملية تدقيق مشروعات القوانين .
الختلفة، وعليه فأن السياسة التشريعية هي في حقيقتها انغكس للسياسة العامة في الدولة، ولما كانت الأمور كذلك فأن الاهتام بمسألة المراجعة القانونية ليس مجرداً

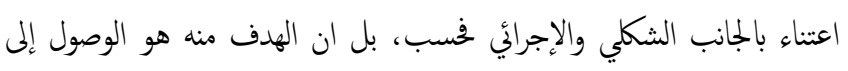
تطبيق دولة القانون من خلال سن تشريع جديد ومتكور في الصياغة مستقيم مع الدستور ويمتد متعارض مع القوانين الأخرى، وأن يكون مفهوم لدى عامة الناس وقابل للتطبيق.

\section{1}

التشريعات المتخصصة بمجلس الدولة في اغلب الدول اضافت الى عمليتي الاعداد والصياغة عملية اخرى يطلق عليها التدقيق، والتي يمكن اعتبارها اهم المراحل واكثرها دقة وذلك لكون عملية الاعداد تتعلق بجمع المواد الوولية والفكرة القانونية لتزكيب مشروع التشريع، وان الصياغة تتمثل بتوليف هذه المواد والافكار على شكل نصوص قانونية ، بينا التدقيق او المراجعة تتمثل بإعادة النظر على مشروع قانوني تم اعداده وصياغته بشكل يتطلب البحث في تحقيق هذا النص للأهداف التي تكون ضمن السياسة التشريعية للدولة وتنصب في المصلحة العامة بحيث يجقق الغرض المنشود من اصدار التشريع وتجنب المشاكل او العوائق التي تظهر عند اصداره وتنفيذه من قبل الحكومة او اثناء تطبيقه من قبل المحاك. 


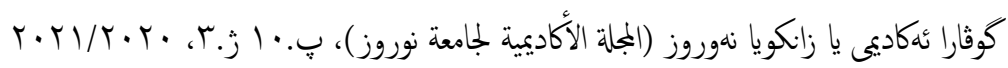

المراجعة (بضم الميم من رجع، أي العودة إلى الأمر من جديد، ومنه مراجعة القضية يعني إعادة النظر فيها، ويقال راجع المعجم أي بحث فيه، وراجع الكلام جعله يعيده ليتأكد منه، وراجع المحاسب الحساب، أي دققه (2).

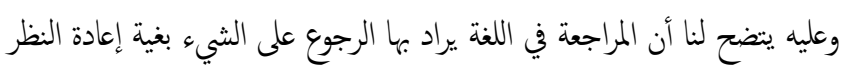
فيه بهدف التحقيق أو او الاتقان او ضبط الشي بعد اعادة النظر او البحث فيه ، اي ان التدقيق لايعني انشاء او صنع او بناء شي ء او سن قاعدة جديدة ، بل تعني ضبط واحكام واعادة البحث والنظر في قاعدة او مجموعة قواعد موجودة بهدف احكامها وضبطها بشكل يرتجى منه تحقيق الغرض المنشود من سنه.

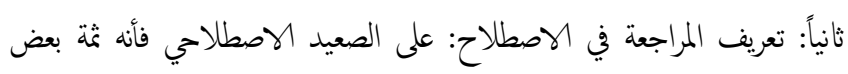
التعاريف التي تم وضعها لمصطلح المراجعة، حيث عرفها البعض على أنها (عملية منهجة وفق أسس علمية محددة وخطوات واضحة هدفها الوقوف على مدى مراعاة التشريع للجوانب الشكلية والموضوعية واللغوية والسياسات التشريعية ذات

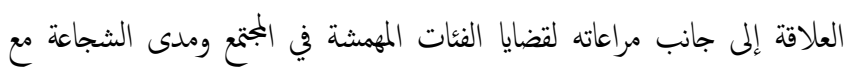

توجحات الدولة وسياساتها ومدى مواءمتها مع الاتفاقيات والمعايير الدولية)(3). كما جرى تعريفها على أنها (عبارة عن دراسة قانونية فنية هدفها رفع أي تعارض في

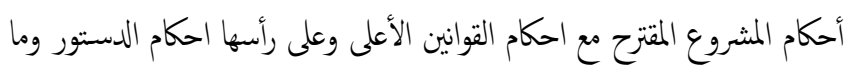
يجيل إليه من أصول مرجعية وما يقرره من مبادئ وما يوجته من توجيهات أساسية في تحقيق الانساق والتجانس بين مواد المشروع المقتح وفيا بينها وبين

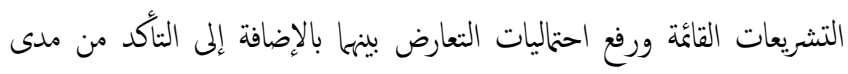
ملائمة الأحكام التفصيلية والإجرائية للمشروع للأهداف الكلية المرجوة من سن التشريع، ومدى صلاحيتها لتحقيق المصالح العامة المطلوب تقريرها...(4). عليه يتضح لنا من خلال ما تقدم بأن عملية مراجعة مشروعات التشريعات يتجلى الهدف أو الغرض الاساسي منها في رفع اي تعارض ريما يكون موجوداً بين احكام القانون المراد إقراره وبين أحكام القواعد القانونية الأخرى الموجودة وفي مقدمتها الدستور فهو (المرجع) ويعتبر بمثابة رقابة استباقية تحول دون اصدار قانون غير دستوري، أو لا يراعي مصاح الدول أو الغايات التي تسعى إلى تحقيقها، ولما كان الأمر كذلك فأن الأمر يتطلب أن تكون الجهة القائمة بهذه العملية على درجة كيرة بنفاصيل القوانين فضلاً عن توافر المقدرة اللغوية لديهم. وهذا ومما تجدر الإثارة إليه في هذا الصدد إلى أن عملية التدقيق او المراجعة لا تقتصر على التشريعات الصادرة عن السلطة التشريعية فقط، وإنا تشمل

\section{1 صعوبات موضوع البحث}

لقد تجسدت اهم الصعوبات التي وابهتنا في كتابة هذا البحث بقلة المصادر التي تناولت هذا الموضوع بالتحليل خصوصاً في العراق ، لذلك حاولنا التأسيس لدراسة تتناول هذا الموضوع بشكل دقيق من خلال الاعتماد على النصوص القانونية فضلاً عن بعض المصادر الفقهية .

\section{1}

من أجل الإحاطة بمردات هذا البحث من جوانبه كافة فقد ارتئينا إلى تقسيمه الى بلى ثلاثة مباحث الاول نخصصه لمعرفة ماهية تدقيق مشروعات التثريعات والثاني نبحث فيه شروط واجراءات تدقيق مشروعات التشريعات اما الثالث فنتطرق فيه الى مضمون التدقيق والزامية عرض مشروعات التشريعات على مجلس الدولة لتدقيقها .

\section{2. المبحث الاول: ماهية تدقيق مشروعات القوانين}

ان البحث في مفهوم تدقيق القوانين أو مراجعتها تطلب منا التطرق إلى تعريف المراجعة أو التدقيق ومن ثم بيان المبادئ الأساسية التي تقوم عليها هذه المراجعة،ومن ثم نتطرق الى بيان الجهة المختصة بالتدقيق وهذا ما دفعنا إلى تقسيم

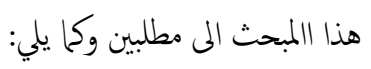

\section{2 المطلب الاول: مفهوم تدقيق مشروعات القوانين والمبادى الهاسية لها} مما لاشك فيه ان تدقيق المشروعات ليس بلامر السهل وانما هي عملية تتبع عدة مراحل واجراءات اضافة الى مراعاة بعض المبادىء والقواعد والشروط لذلك لابد من تعريف التدقيق ابتداءا ثم بيان المبادىء التي تقوم عليها من خلال الفرعين

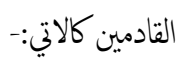

\subsection{2 الفع الأول: تعريف تدقيق مشروعات القوانين}

قبل التطرق إلى التعريف الفقهي لمراجعة أو تدقيق مشروعات القوانين سنشير إلى التعريف اللغوي، لذلك ارتأينا إلى تقسيم هذا الفرع على فقرتين وكما يلي: أولاً: التعريف اللغوي لمراجعة مشروعات القوانين: الملاحظ على مشروعات القوانين أنها مصطلح مركب يتكون من مقطعين الأول (مشروعات) والثاني (قوانين) وإذا ما اضفنا إلى النعريف اللفوي مصطلح مراجعة فأننا سنكون أمام ثلاث مفردات تتطلب التعريف بها لغوياً وكما يلي:-

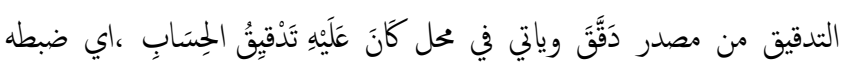
بامعان بالتدقيق اي بالضبط او باحكام او باتقان اما المراجعة: 


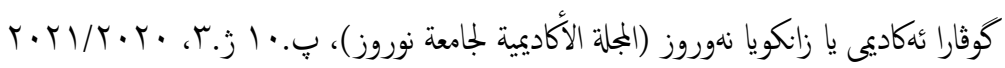

إطار (حدود) رقابة المشروعية التي يلتزم بها قسم التشريع في مجلس الدولة)(7).

- مانيا/ عدم إبداء الرأي في المسائل التي تخزج عن نطاق الصلاحيات حيث

تكون الجهة صاحبة المشروع محتاجة إلى رأي قانوني يتعلق بالمشاكل توابحها لذلك فهي تلجأ إلى جهة الافتاء المتخصصة كون إبداء الرأي والمشورة يخرج من صلاحيات الاختصاص التشريعي لمجلس الدولة ويدخل ضمن نطاق اختصاص المشروعة وابداء الرأي، ولا يملك أيضاً إحلاة المشروع إلى الجهة المعنية بل فقط عليها أن تعيد المشروع أو الطلب إلى الجهة المرسلة مع بيان عدم تخصصها بهذا الموضوع. - - مثالثا/ ويختص مجلس الدولة في تدقيق مشروعات التشريع برفع التناقض بين أحكام المشروع أحكام واردة في التشريع القائم ولا يعد خروجاً عن اختصاصه، بل أن من جل اختصاصات قسم التشريع مراعاة التدرج

\section{القانوني ورقع التناقض (8).}

- - رابعا/ مراعاة التدرج الهري للقواعد القانونية يعد من جوهر عمل مجلس الدولة في مراجعة وتدقيق مشروعات التشريعات حيث تعد الرقابة الوقائية أو الرقابة المسبق لدستورية القوانين، ولذلك نلاحظ قسم التشريع في مجلس الدولة المصري حيث أن أول عمل يقوم به هو التحقق بأن التشريع صدر من الجهة الختصة بإصداره قانوناً، إضافة إلى عدم مخالفة المشروع الدستور إذا كان قانوناً (تشريعاً عادياً) وعدم مخالفنه للقوانين والدستور إذا كان لائحة. - خامسا/ على مجلس الدولة ان تنبه الإدارة حول ما سيئول إليه الوضع عند تطبيق المشروع المقترح وإنذارها إلى ما قد يتطلبه من بحث أو مراجعة، وذلك بسبب أهمية المشروع أو خطورة التدخل التشريعي المقتح، دون أن كون تورطاً في تقدير الملائمة المشروع أو خروجاً من اختصاصه(9). - - مادسا/ لا يشمل اختصاص مجلس الدولة بما ستؤل إلها الأمور بعد إتمام مراجعة المشروع حيث أن المجلس يصدر تقرير بشأن المشروع وييين التعديلات التي يجب إجراءها دون أن يكون له الشأن بمتابعة هذه الإجراءات والتعديلات لأنها تخج عن نطاق وظيفته وإنما يعتمد ذلك على
التشريعات الثانوية ايضاً، ويراد بهذا النوع الأخير تلك التشريعات التي تصدر عن السلطة التنفيذية وهي غير مستقلة بذاتها وإنما تتبع القانون الذي تأتي لتنفيذه فلا تتعدى همتها الاساسية أو الهدف منها وهو تنفيذ القانون، حيث تخضع هذه

التشريعات الثانوية من قبل عدة جهات وهي: (5)

$$
\text { - - - م المراجعة من قبل الصائغ نفسه. }
$$

- - م المراجعة من قبل متخصص باللغة العربية.

وبالعودة إلى عملية مراجعة التشريعات الصادرة عن السلطة التشريعية سيتضح لنا أن هذه المراجعة تقسم إلى عدة أنواع تمثل بما يلي:- (6) المراجع اللغوية: تتم هذه المراجعة من خلال مراجعة مشروع التشريع من حيث الجوانب والأصول اللغوية في الصياغة التشريعية ومدى مراعاة التشريع لهذه الأصول عند الصياغة كأسلوب للتعبير القانوني. المراجعة القانونية: تتم من خلال خص عدم مخالفة التشريع الأدنى للتنشيع الأعلى وبشكل أكثر دقة، اضافة الى انه يتوجب مراعاة الاجراءات المتبعة في صياغة القاعدة القانونية يجب أن يأتي التشريع مستوفياً للشكل الواجب اتباعه وفق للقانون الأساسي المعمول به في الدولة. مراجعة سياسات التشري: تتم هذه المراجعة من خلال ربط التشريع بالسياسة التشريعية التي توخاها واضعوا التشريع والربط مع المشكلة الاساسية التي استهدف التشريع حلها.

\subsection{2 الفزع الثاني: المبادئ التي تقوم عليها تدقيق مشروعات التشريعات}

ثمة جملة من المبادئ لابد من توافرها للقيام بعملية تدقيق لمشروعات القوانين وهذه المبادئ لها صلة بشكل مباشر بالقانون المراد مراجعته ويكن اجال هذه المبادئ بما

- - اولا/ تدقيق المشاريج لا يشمل الملائمة الموضوعية: ويقصد بهذا المبدأ آن تدقيق المشروعات في مجلس الدولة (قسم الختص بها) يكون فقط ضمن إطار فكرة المشروعية دون التطرق إلى الملائمة، مثلاً عندما (قرر قسم التشريع بأن العقوبة في الشروع قد بدت صارخة بالنسبة للأفعال التي أجرمتها المشروع إلا ان ذلك يدخل في تقدير ملائمة الموضوع التي تتزخص بها السلطة التنفيذية تحت رقابة السلطة التشريعية دون أن تكون ضمن 


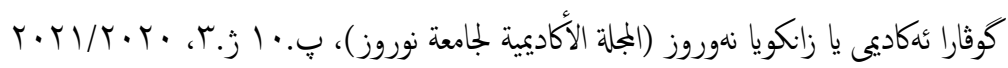

قد فسرت الحكومات المتعقبة في فرنسا على تفسير هذا النص بأنه ملزم للحكومة بعرض مشروعات القوانين على المجلس لإعداد مراجعتها وصياغها من ناحية التوافق مع الدستور قبل عرضها على البرلمان، ثم جاءت في المادة (39) من

$$
\text { دستور عام } 1958 \text { مؤيدة هذا النكيف لمجلس الدولة(10). }
$$

وبعد صدور قانون مجلس الفرنسي ذي الرق (64) لعام (1972) بدأ المجلس مرحلة جديدة من القضاء المستقر أي من القضاء المقيد إلى القضاء المفروض حيث وسع من اختصاصات الحكومة للنظر فهيا واعدادها بالصيغة التشريعية اللازمة مع مراجعتها مع ما يتفق من الدستور والقوانين الأخرى، هذا وقد أكدت من السلطة التشريعية في فرنسا في العديد من قراراتها الإدارية في الدولة أن تتجاوزه لما له من دور في فن الصياغة وإذا لم يتم عرضه على المجلس كهيئة استشارية فلا يجوز النظر التي فيه من الناحية التشريعية لفقده الركن أو ركنين من أركان التشريع (11).

\subsection{2 الفرع الثاني: الجهة المختصة بتدقيق مشروعات القوانين في مصر} أن الجهة المختصة بمراجعة مشروعات القوانين في مصر هو قسم التشريع والذي هو أحد الاقسام التابعة لجلس شورى الدولة المصر، وهنا نود التنويه إلى أن قسم التشريع قد واجه عدة أمور قبل أن يستقر كقم يختص بالمراجعة وفق الصياغة ففي ظل القانون رقٌ (112) لسنة (1946) وهو أول قانون ينظم مجلس الدولة في مصر والذي جعل مل من قسم الفتوى ينتقل من قسم التشريع باستثناء ما نصت عليه المادة (19) والتي أجازت أن يشترك في جلسات قسم التشريع أحد مستشاري الفتوى، ثخ صدر يعد ذلك القانون رقٌ (165) لسنة 1955 حيث عمل هذا القانون على دمج الفتوى التشريع(12). ثم وضح القانون رقٌ (55) لسنة 1959 سبب هذا الدمج والذي تم تبريره في الجمع بين تفسير التشريع بعد الاقناء إن صاغة قسم التشريع(13)، وبعد ذلك صدر القانون رقٌ (47) لسنة 1972، وجعل كلاً من قسم التشريع وقسم الفتوى اقسام مستقلة عن بعضها. هذا وقد بينت المادة (62) من قانون مجلس الدولة المري رق 47 لسنة 1972، بينت آلية تكوين هذا القسم (قسم التشريع) حيث نصت المادة أعلاه على (يشكل قسم التشريع من أحد نواب رئيس المجلس ومن عدد كاٍٍ من

$$
\text { المستشارين والمستشارين المساعدين ويلحق به نواب ومندوبين....). }
$$
والزمت المادة (63) من القانون ذاته الوزارات كافة يعرض مشروعات قوانيها على قسم التشريع قبل اصداره، حيث نصت المادة أعلاه على ما يلي (على كل وزارة
إلزامية الأخذ بآراء المجلس وتعديلاته من عدم الالتزام بها. وهذا ما

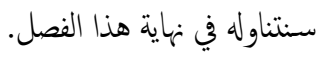

\section{2 المطلب الثاني: الجهة المختصة بمراجعة مشروعات التشريعات} تعتبر عملية مراجعة مشروعات القوانين بمثابة الرقابة السابقة على صدورها (مشروعات القوانين) وهذه الرقابة لها أهمية كيرة جداً لأها تكفل للتشريع الدقة وحسن الصياغة وكمال التنسيق والتوافق بين التشريعات، حيث من المهم جداً أن تكون هناك عملية مراجعة أو تدقيق لمشروعات القوانين قبل اعتادها أو اصدراها أو نفاذها وذلك للحيلولة دون الوقوع في الأخطاء بمعناها الواضح (الموضوعية منه واللغوية). هذا وقد تطرقنا في المطلب الأول من هذا المبحث إلى المبادئ العامة المتعلقة بالمراجعة، وسنسلط الضوء في هذا المطلب على الجهة المختصة بعملية المراجعة، ولما كانت دراستنا، دراسة مقارنة اعتمدنا من خلال على العراق وكل من فرنسا ومصر، لذلك ارتأينا إلى تقسيم هذا المطلب إلى فرعين، حيث سنشير في الفرع الأول إلى الجهة الختصة بالمراجعة في مجلس الدولة العراقي والدول محل المقارنة (فرنسا ومصر) أما الفرع الثاني فقد خصصناه للإشارة إلى مضمون التدقيق وكما

\subsection{2 الفرع الأول: الجهة المختصة بتدقيق مشروعات التشريعات في فرنسا} من المعلوم ان العداد القوانين وصياغتها ليست حكرا عند بجة او مؤسسة رسمية معينة فقد يكون السلطة التنفيذية من تقوم باعدا] المشاريع او اعضاء المجالس النيابية ونفس الحل بالنسبة للصياغة وقد تعهد هذه الموسسات او السلطات هذه المهمة الى مجلس الدولة بينا تدقيق المشاريع بصورة صحيحة (فنية وعملية ) لايمكن تصورها الا في ججلس الدولة وقد يكون مجلس الدولة قد اناط هذه المهمة بقسم محدد او بجة معينة بداخله ولذلك سنشير في هذا الفرع إلى الجهة المختصة بمراجعة مشروعات القوانين وإجراءاتها في كل من مصر وفرنسا والعراق و، يعتبر مجلس الدولة الفرني بمثابة اكبر هيئة استشارية في فرنسا وكان من أولويات اختصاصه أن يكون مستشاراً للحكومة في مراجعة وصياغة القوانين والتشريعات، كما أنه قد ساهم مع الحكومة في إعداد مشروعات القوانين ثم يقوم بمراجعها ويعيد صياغها فنياً، مؤقتاً للأمر العالي الصادر عام 1945 (قانون ججلس الدولة الفرنسي) والذي نصت المادة (21) منه على (ويشترك مجلس الدولة في اعداد القوانين والمراسيم...) 


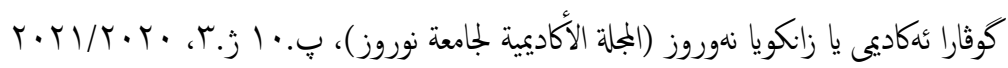

مفاده ضرورة التأكد من عدم خروج النص او تجازه عا هو مقرر بقاعدة تولده في مدارج القواعد التشريعية، حيث تشريع على قتها النصوص الدستورية التي يتعين دائًاً استحضارها مائلة في ذهن واضع التشريع والالتزام بصحيح أحكام الدستور والنزور على أوامره، أيضاً من ابرز الأمثلة على قسم التشريع في مجال مراجعة وصياغة التشريعات ما يل (من مراجعة مشروع قانون الضرائب على الدخل تبين أنه نصت المادة (1) من مشروع القانون على أن تفرض ضريية سنوية على مجموع صافي دخل الأشخاص الطبيعية الواردة ذكرم في المادة (2) من هذا القانون، كما نصت المادة (2) على أن تسري الضريبة على غر المقيمين فيها بالنسبة لدخولم المحققة في مصر ونصر المادة (3) على أن يعتبر الممول مقياً عادة في مصر في أي من الحالات الآتية....) قد قام قسم التشريع بإعادة تدقيق ما اسلفناه وجرى التعديل على النحو التالي (تفرض ضريبة سنوية على مجموع صافي دخل الاشخاص الطبيعية المتمين عادة في مصر، كما تسري الضريبة على غير المقميمن فيها بالنسبة لدخولم المحقة في مصر ويعتبر الممول مقياً عادة في مصر في أي من

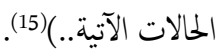

\subsection{2 الفرع الثالث: الجهة المختصة بثدقيق مشاريع القوانين في العراق} اما في العراق فانه لايوجد قسم محدد يقوم بهام التدقيق في مشروعات القوانين لذلك ننوه بالمشرع بانشاء قسم خاص يقوم بهمة الاعداد والصياغة والتدقيق على غرار ما هو موجود في قسم التشريع في مجلس الدولة المصري بل وان يتخذ من

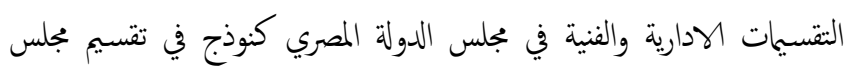
الدولة العراقي اذا نرجوا من المشرع الى تعديل قانون مجلس الدولة وذلك بتقسيم مجلس الدولة الى اقسام واتخاذ المعيار الوظيفي اساسا له وتقسيمه الى قسم التشريع وقسم الفتوى وقسم القضاء وقسم خاص بادراسات واعداد التقارير يكون اتصال وثيق بجميع كليات القانون وبفروع نقابات المحامين والحقوقين والمنظمات والمجعيات التي تعمل بهذا الصدد وخاصة المعنية بحقوق الانسان وذلك للوقوف على الثغرات التشريعية والقواعد التي تسبب بعض العراقيل عند تطبيقها في المحاك او في مؤسسات الدولة . ومن كل ماذكر لايعني بان مجلس الدولة في العراق لايختص بتدقيق المشروعات

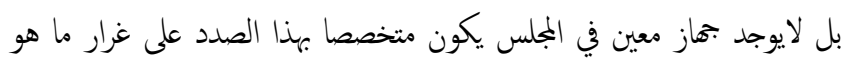
موجود في مصر وفرنسا ، فالتدقيق سوف نتناوله في مجلس الدولة في مبحث

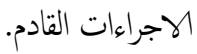

أو مصلحة قبل اصدار أي قانون أو قرار من رئيس المجهورية ذي صفة تشريعية أو لائحة أن تعرض المشروع المقترح على قسم التشريع لمراجعة صياغته وييوز لها أن تعهد إليه بإعداد هذه التشريعات). ومن ناحية أخرى فقد حددت المادة (66) من قانون مجلس الدولة المصري رة 47 لسنة 1972 اختصاصات قسم الفنوى والتشريع بابداء الرأي في المسائل والموضوعات الآتية:أ. المسائل الدولية والدستورية والتشريعية وغيرها من المسائل القانونية التي تحال إليها بسبب أهميتها من رئس الجمهورية أو من رئيس الهيئة التشريعية أو من رئس مجلس الوزراء أو من أحد الوزراء أو من رئيس مجلس الدولة. ب. المسائل التي ترى فيها أحدى لجات قسم الفتوى رأياً يخالف فتوى صدرت من لجنة أخرى أو من الجمعية العمومية لقسمي الفتوى والتثريع. ج. المسائل التي ترى فيها أحدى لجان قسم الفتوى إحالتها إليها لأهيتها. د. المنازعات التي تنشأ بين الوزارات أو بين المصالح العامة أو بين الهيئات العامة أو بين المؤسسات العامة أو بين الهيئات المحلية أو بين هذه الجهات وبعضها البعض.

ويكون رأي الجمعية العمومية لقسمي الفتوى والتشريج في هذه المنازعات ملزمة للجانبين، هذا وفضلاً عما تقدم فأن الجمعية العمومية تختص بمراجعة لمجلس الدولة المصري بمراجعة مشروعات القوانين وقرارات رئس الجمهورية ذات الصفة التشريعية واللوائح التي يرى قسم التشريع إحالتها إلها لأهمينها. وعليه وبشكل عام يكن القول ان قسم التشريع في مجلس الدولة المصري، يعتبر بحاز فني متخصص في مراجعة صياغة مشروعات التشريعات قبل اصدراها ومنع التضارب فيه بيها وبين القوانين الأخرى وبذلك يكون قسم التشريع قد ربط بين أهم النقاط قبل اصدار المشروع للتشريع وهي: - - من الناحية الموضوعية، يتولى قسم التشريع مراقبة مدى اتفاق مشروعات التشريعات مع التشريعات الأعلى. - - ومن الناحية الفنية، فأن قسم التشريع يمتلك الخبرة الواسعة في أصول الصياغة الفنية للقانون(14). وللتوضيح سنورد في هذا الصدد بعض الأمثلة على قيام قسم التشريع بكهة المراجعة الفتوى الصادرة عن قسم التشريع والتي جاء فيها (لئن كانت المراجعة التي يجريها القسم تتطلب بككم اللزوم احكام الصياغة بمراعاة مقتضياتها ومرقيتها، إلا أنها تتطلب قبل ذلك وفي المقام الأول التدقيق في مراعاة متطلبات المشروعية بما 
وعليه وبالاستناد إلى ما تقدم فأن مجلس الدولة الفرنسي لا يبدي رأياً ولا يختص بتدقيق مقترحات أو مشروعات التشريعات غير الموضوعية كلتي تتعلق بالموازنة(18)، والحسابات والقروض، وكذلك لا يختص بتدقيق المشاريع التشريعية

التي تستهدف الأفراد فقط.

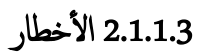

تختلف الجهة التي تقوم بأخطار مجلس الدولة الفرنسي باختلاف النص المعروض عليه فإذا كان النص عبارة عن مشروع قانون أو مشروع أو أمر أو مرسوم مجلس الدولة أو مرسوم في مجلس الوزراء فأن الجهة المكلفة بالأخطار هي الأمانة العامة للحكومة الفرنسية، أما إذاكان النص عبارة عن اقتراح قانون من قبل النواب فأن الجهة المكلفة بالأخطار في هذه الحالة هي رئس الجمعية الوطنية، وفي حال ما إذا كانت الجهة المقترحة للقانون هم أعضاء مجلس الشيوخ فأن رئيس هذا المجلس هو المكلف بالأخطار ، وإذا كان مشروع النص عبارة عن مرسوم عادي فأن الجهة التي

$$
\text { تقوم بالأخطار هي الوزارة المعنية(19). }
$$

3.1.1.3 أن يرفق بمشروع النص المراد تدقيقيه عناصر الملف تتولى أحدى الجهات المعنية بالأخطار والتي تم ذكها آنفاً ارسال مشروع النص المراد تدقيقه ويجب ان ترفق معه الوثائق الضرورية والتي تتكون مما يلي: مذكرة توضيحية: ويراد بهذه المذكرة، الملخص الذي يرافق مشروع القانون والذي يبين بشكل عام أسباب وجوده والهدف منه وتأثيره على الأوضاع القائمة والغاية منها أن تكون دليلاً مقيداً في التعرف على القصد من التشريع المقترح وكذلك لاطلاع القارئ على ما يسعى القانون إلى تحقيقه ومن الطبيعي أن تتضمن هذه المذكرة معلومات عامة عن المشروع المراد تدقيقه مقل (عنوان المشروع، الجهة المقترحة، تاريخ تقديم المشروع، الأهداف المراد تحقيقها منه، المشاكل القائمة والأسباب التي تدعوا إلى تغير القائم والتوجه العام لتصحيحه والتشريعات النافذة ذات العلاقة بموضوع المشروع

$$
\text { ووصف موجز لمواد المشروع....(20). }
$$

دراسة الأثز: وهي جزء من الأعال التحضيرية لمشروع التشريع والغرض منها هو تقيم الآثار الاقتصادية والمالية والاجتاعية والبيئية لمشروع القانون المعروض على مجلسي البرلمان (بجلس الشيوخ، الجمعية الوطنية) ومن المؤكد أنها تتم قبل ان يتم إحالة مشروع القانون على مجلس الدولة.

\section{3. المبحث الثاني: شروط واجراءات تدقيق مشروعات التشريعات} ان كل مرحلة تمر بها مشروعات التشريعات في مجلس الدولة تحتاج الى بموعة من الاجراءات والشروط التي يستلزم توافرها واتباعها بهدف اضفاء الشرعية القانونية على هذه العملية عليه نتسم هذالمبحث الى مطلبين الاول نسر فيه الشروط اللزمة لندقيق مشروعات التشريعات في مجلس الدولة والثاني نبين فيه الاجراءات الواجب اتباعها في تدقيق مشروعات التشريع كلاتي :

1.3 المطلب الأول: شروط تدقيق مشروعات القوانين امام بجلس الدولة يشترط لقيام مجلس الجولة في الدول محل الدراسة (فرنسا، مصر، والعراق) توافر جملة من الشروط أخذنا على عاثتنا بيانها في هذا المطلب في ثلاث فروع مستقلة

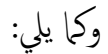

\subsection{3 الفرع الأول: شروط تدقيق مشروعات التشريعات في مجلس الدولة} الفرنسي يضم مجلس الدولة الفرنسي جملة من الاقسام الإدارية، حيث تتولى هذه الأقسام كمة صياغة مشروعات القوانين التي تتقدم بها الحكومة الفرنسية للبرلمان، كما تقوم هذه الأقسام إلى جانب ما تقدم بصياغة مشروعات المراسيم الجمهورية التي لها قوة القانون حقيقاً للدستور، فضلاً عن توليها صياغة مشروعات الأنظمة الإدارية الهامة(16). وهنا نود التنويه إلى أنه يشترط لمارسة مجلس الدولة الفرنسي اختصاصه الاستشاري في تدقيق مشروعات القوانين توافر جملة من الشروط يككن اججالها بما يلي:

\subsubsection{3 ان يكون مشروع النص المراد تدقيقه ذات طبيعة تشريعية} براد بهذا الشرط أن يكون محلس مشروع النص المراد تدقيقيه ومراجعته من قبل مجلس الدولة متضمناً إنشاء قواعد عامة مجردة أو التعديل عليها، فقوام التشريع كما هو معروف أنه يضع قواعد عامة مجردة تطبق على الأفراد بصفاتهم وليس بذواتهم لذلك لا يعتبر تشريعاً أو قاعدة تشريعية، ما يتم إصداره من قبل سلطة عامة مختصة في الدولة خاصة بشخص معين أو واقعة معينة بذاتها، حتى وإن كان قد صدر عن سلطة عامة مختصة بإصداره لعدم انطوائه على قاعدة عامة مجردة، حيث لا يخاطب طائفة غير محددة من الأفراد(17). 


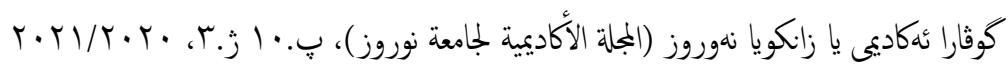

ترديداً لأحكمه، فأن مراجعة هذا المشروع لا فائدة منه وعليه واستناداً إلى المعنى المتقدم فأن هناك العديد من الموضوعات التي تخرج عن اختصاص مجلس الدولة قدر تعلق الأمر بالتدقيق ومن أهم تلك الموضوعات ما يلي:-

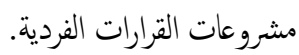
مشروعات التعليمات الإدارية الداخلية. قرارات التفويض في الاختصاص.

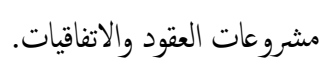

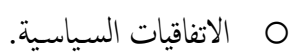

$$
\text { O }
$$

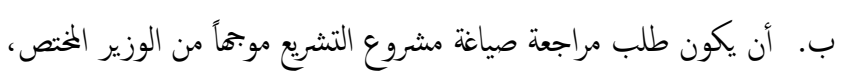
حيث يجب أن يوجه طلبات المراجعة إلى مجلس الدولة من قبل الوزير المختص وأن يتضن الكناب الموجه للقسم ما يفيد موافقة الوزير على السير في إجراءات المشروع بصورته المطروحة(24). أي وجود طلب مكتوب موقع من الوزير يتضمن إعادة أو مراجعة صياغة مشروع التشريع، ذلك كون المادة 63 من قانون مجلس الدولة يشر إلى (على كل وزارة لأن تعرض) حيث من البدهي أن الوزارة شخص معنوي وأن من يرأسها هو

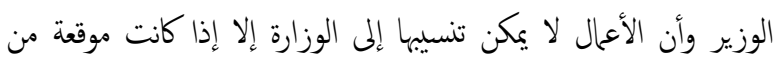
الوزير ، إضافة إلى أن يكون الوزير هو صاحب الاختصاص حين التوقيع والنظر في المشروع(25). وأن أي مشروع يرسل إلى قسم التشريع دون توقيع الرئيس الأول للمؤسسة أو الوزير فأنه يتم إعادة المشروع إلى الوزير

$$
\text { بدون مراجعة صياغته (26). }
$$

ج. أن تكون جهة الإصدار من أنشاص القانون العام وهذا ما ظهر بشكل واضح في المادة 63 المذكورة آنفاً حيث توجي أن تكون الجهة المرسلة لطلب مراجعة الصياغة أو الإعداد أما وزارة أو مصلحة عامة والوزارة عبارة عن اقسام إدارية وليست تخصص باختصاص معين، أما المؤسسات العامة فهي اشخاص إدارية تتمع بالشخصية المعنوية تحديد وفقاً ذي نشاط زراعي أو صناعي أو مالي، وتسمى هذه الأشخاص الإدارية الهيئات العامة إذا كان المرفق الذي تديره يقوم خدمات عامة(27.)
الثأثيرات: يجب ان يرفق بمشروع النص المراد تدقيقه بطاقة تضم جميع التشريعات المتعلقة بالاستشارات التي يستوجها النص من الهيئات المعنية والغرض من التشريعات هو تسليط الضوء التي ينطبق عليها المشروع وتلك التي تعدل، فضلاً عن ذكر الأحكام التي تنص على تدخل مجلس الدولة أو المؤسسات أو الهيئات الأخرى التي كانت من الضروري إجراء مشاورات مسبقة بشأنها.

$$
\text { اسماء الوزراء المعنيين بالمشروع (21). }
$$

\subsection{3 الفرع الثاني: شروط تدقيق مشروعات التشريعات في مجلس الدولة}

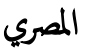

ذكرنا فيا سبق بان قسم التشريع في مصر هو المختص مراجعة صياغة المشاريع

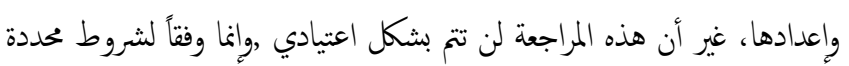
ومقررة في المادة 63 و 64 من قانون مجلس الدولة المصري، ولكون قسم التشريع هو الختص بهذا العمل فان لوائحه الداخلية أيضاً تنظم هذا الشأن غير أنه لا يكن أن ننسى بأن قسم التنريع هنا يختص بمراجعة صياغة مشروعات التشريعات التي ترسل إليه من الحكومة أي مقترحات الحكومة وليست مشاريج أعضاء مجلس الشعب، ومن أهم شروط مراجعة صياغة مشروعات التشريعات (تدقيقها) هي: أ. يجب أن يكون المشروع ذات صفة تشريعة. هذا المبداً يراد به ان يكون المشروع المراد مراجعته أو تدقيقه متضمناً قواعد عامة جردة، فصفة العمومية والتجريد من تعتبر أحدى المستلزمات الواجب توافرها في المشروع الذي في الشبة مراجع، فالعمومية تعني هنا أن يخاطب المشروع الأفراد بصفة عامة سواء من حيث الأمر أو النهي، وأيضاً تعني العمومية أن يكون الخطاب عاماً من حيث المكلن بمعنى أن لا ينحصر تطبيقه في جزء معين من أجزاء الدولة دون بقية الأجزاء بل يجب أن يشمل كل إقليم الدولة فهي اي القاعدة القانونية تتجرد من حيث الأشخاص والمكان والوقائع أيضا(22)هذا يعني ووفق للخاصية أعلاه أن القاعدة القانونية يجب أن تطبقه على الجميع اي من تتوفر فيهم شروط التطبيق دون النظر إلى اشخاصهم أو اسائه. وأيضاً يجب أن يكون المشروع المطلوب مراجعته متضمناً قواعد جديدة لم تصدر بعد أو ادخال تعديل على قواعد قائمة أما إذا كان المشروع المطلوب مراجعته يعد تكراراً لا طائل منه لأحكام قانون قائم ولا يعدو ان يكون 


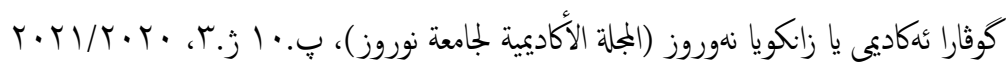

ثانياً: تدقيق جميع مشروعات التشريعات المعدة من الوزارات او الجهات غير المرتبطة بوزارة، من حيث الشكل والموضوع على النحو الاتي: أ. تلتزم الوزارة الختصة أو الجهة غير المرتبطة بوزارة بارسال مشروع التشريع الى الوزارة أو الوزارات أو الجهات ذات العلاقة لبيان رأهها فيه قبل عرضه

$$
\text { على المجلس. }
$$

ب. يرسل مشروع التشريع المى البملس بكتاب موقع من الوزير الختص أو الرئيس الاعلى للجهة غير المرتبة بوزارة مع اسبابه الموجبة واراء الوزارات

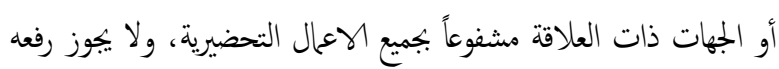

الى ديوان الرئاسة مباشرة إلا في الاحوال التي ينسبها الديوان...). عليه يتضح لنا من خلال ما تقدم أنه يشترط لقيام مجلس شورى العراقي بعملية تدقيق مشروعات التشريعات توافر جملة من الشروط يككن إجالها بما يلي:

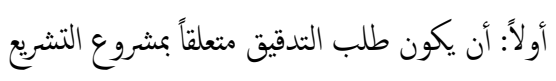

يراد بهذا الثرط ان طلب الجهات ذات العلاقة من المجلس بتدقيق مشروعات معدة من قبلها وصياغتها يجب أن ينصب على مشروعات التشريعات وهذا يعني أنه لا يجوز الطلب من المجلس بتدقيق أية مشروعات أو صياغتها لا تحمل صفة

$$
\text { التشريع ويراد بلفظ التشريع هنا ما يلي: }
$$

القواعد العامة المجردة التي تصدر بشكل مكتوب عن السلطة الختصة في

التشريع ذات القاعدة القانونية التي تسنها السلطة المختصة أو على بموعة من

$$
\begin{aligned}
& \text { تلك القواعد التي تشترك في تنظيم أمر من أمور الجماعة(29). } \\
& \text { ثانياً: الوقوف على رأي الوزارات أو الجهات ذات العلاقة بالتثريع }
\end{aligned}
$$

يشترط قانون مجلس الشورى في العراق على الوزارات والجهات غير المرتبطة بوزارة عندما تطلب من المجلس إعداد أو صياغة أو تدقيق مشروع تشريع أن ترافق آراء الوزارات والجهات ذات العلاقة، فإذا احتوى المشروع أموراً مالية أو اقتصادية فيتضضي استحصال موافقة وزارة المالية وإذا كان له علاقة بالسياسة العامة للدولة فيتضضي الأمر الحصول على موافق ورأي الأمانة العامة لجلس الوزراء ووزارة الخارجية وهكذا(30. ويفسر هذا الأمر لضان صحة التشريع ولوجود قواعد تعني فيها أو تشترك في تنظيمها أكثر من جهة هذا وقد دلت التجربة العملية أن معظم الوزارات والجهات غير المرتبطة بوزارة لا تطبق هذا الأمر المشار إليه في أعلاه أي لا تلتزم بعرض تهر
د. أن يكون المشروع مشفوعاً بالمذكة الايضاحية التي توضح فهيا بيانات المشروع ومبرراته وبيان طلب إعداد المثروع أو مراجعة صياغته وعدم ارفاق هذه المذكرة الإيضاحية يجعل من قسم التشريع عدم النظر في هذا المشروع وذلك استناداً لما ذكر في نهاية المادة الـ 63 (مشفوعة بمذكة إيضاحية). هـ استنفاد مراحل الاعداد والدراسة من قبل الجهة الطالبة يشترط لمارسة مجلس الدولة لمهمة المراجعة لمشروعات القوانين أن تكن الجهة الطالبة للمراجعة قد استنفت مراجل الاعداد والدراسة وانها قد ارتضت من وبجة نظرها المشروع المعروض على مجلس الشورى لغرض مراجعته على اعتبار أن مراجعة الصياغة هي مرجلة ما قبل الاصدار مباشرة، وعليه لا يصح عرض المشروع على مجلس الدولة وفي نشس الوقت تقوم لجنة في جهة أخرى بدراسة نس المشروع حيث ان اختصاص مجلس الشورى بمراجعة مشروعات القوانين إنما يكون بعد استكمال دراسة المشروع من جميع جوانبه من الجهات المختصة وتبادل وبجات النظر فيها تضمنه من احكام موضوعية، وعليه وتطبيقاً لذلك قرر قسم التشريع في مجلس الدولة المصري ان عملية صياغة التشريعات هي المرحلة الأخيرة في خطوات اعداد التشريع بعد استنفاذ إجراءات النظر فيه من النواحي الموضوعية بمعرفة جميع الجهات الختصة بذلك قانوناً، لذلك فان الأمر يقتضي استنفاذ جميع الإجراءات أولاً

$$
\text { قبل عرض المشروعات على قسم التشريع لمراجعة صياغتها. }
$$

\subsection{3 الفرع الثالث: شروط تدقيق مشروعات التشريعات في مجلس الدولة}

العراقي

يتولى مجلس الدولة العراقي العديد من الوظائف، وهذا ما يمكن استنتاجه من نص

$$
\text { المادة (4) من قانون ذي الرق (65) لسنة (1979) (28). }
$$

وفي هذا الصدد نصت المادة (5) من قانون مجلس الدولة المشار إليه آنقاً على ما

$$
\text { يلي (مارس المجلس في مجال التقنين: }
$$

أولاً: اعداد وصياغة مشروعات التشريعات المتعلقة بالوزارات أو الجهات غير بن برن المرتبطة بوزارة بطلب من الوزير الختص أو الرئيس الهعلى للجهة غير المرتبطة بوزارة بعد ان يرفق بها ما يتضمن اسس التشريع المطلوب مع جميع اولياته واراء الوزارات أو الجهات ذات العلاقة. 


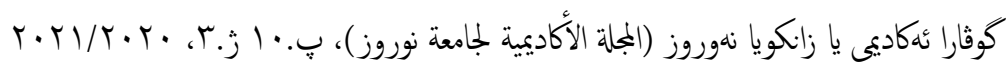

2.3 المطلب الثاني: إجراءات تدقيق مشروعات التشريعات امام مجلس الدولة

تخضع عملية تدقيق مشروعات التشريعات أمام مجلس الدولة لمجموعة من الإجراءات والقواعد، والتي ارتأينا الإثارة إيها في هذا المطلب في ثلاث فروع

مستقلة وكما يلي:

\subsection{3 الفرع الأول: إجراءات تدقيق مشروعات التشريعات في مجلس الدولة}

الفرني

ثمة مجموعة من الإجراءات المتبعة أمام مجلس الدولة الفرنسي أثناء ممارسة وظيفته في

إطار تدقيق مشروعات التشريعات، سنشير إليها في هذا الفرع وكما يلي:

1.1.2.3 تهيئة المشروع

ان عملية تهيئة مشروعات التشريعات بقصد تدقيقها تمر بعدة مراحل يككن إجلالها

بما يلي:

تسجيل مشروع النص وإيداعه: حيث تقوم الجهة الخطرة بارسال النص

المراد تدقيقه إلى الأمانة العامة لجلس الدولة الفرنسي وترفق معه عناصر

الملف الخاص بالنص وبواقع نستين وبعدها يتسلم الأمين العام لمجلس

الدولة مشروع النص ويسجل في سبحل خاص حسب ترتيبه الزمني (34.

تعين مقرر وإعداد التقرير: بعد ان يتم تسجيل المشروع يقوم رئيس مجلس

الدولة بإحالته إلى أحد الأقسام ويقوم القسم بتسجيله عن طريق تعين رقز له وبعد ذلك يقوم رئس القسم المحال إليها النص بتعين مقرر أو عدة

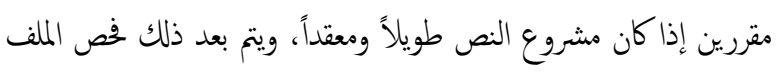
ودراسة مشروع النص من جوانبه كافة وللمقرر وهو يقوم بهذه العملية أن يستعين بالآراء السابقة للمجلس حول المشاريع التي هي من نفس الميدان، وللمقرر من القسم الاستشاري سلطة استدعاء الموظف المختص أو الممثلين للوزارة المعنية بالمشروع وكل من له علاقة باقتراح المشروع والاجتماع بهم والاستماع إبيه عن طريق الاجتماع الذي يعقد داخل مجلس الدولة، بعدها يقوم المقرر بصياغة مشروع النص وتقديمه إلى القسم ليتم تداوله بين الأعضاء الذين يتزاوح عددهم بين (15 - 20) عضو بين

$$
\text { مستشار دولة ونائب ومندوب(35). }
$$

2.1.2.3 مناقشة مشروع النص والبت في الرأي
المشروع على الجهات ذات العلاقة المثئثة بالتشريع أما لعدم المعرفة بإجراءات الصياغة التشريعية أو الحنشية من الرأي السلبي لتلك الجهات مما يضطر في هذه

الحالة للقيام بما يلي: (31)

أما إعادة المشروع إلى الجهة طالبة التشريع لاستحصال آراء الجهات ذات العلاقة ومن تطبيقات ذلك إعادة مشروع تعليمات تسهيل تنفيذ قانون مؤسسة السجناء السياسيين رق (4) لسنة (2006) إلى مؤسسة السجناء السياسيين حيث وجد المجلس أنه لم يتم أخذ آراء الوزارات والجهات ذات العلاقة بالمشروع استناداً إلى أحكام الفقرة (ب) من البند (ثانياً) من المادة (5) من قانون المجلس.

قبول المشروع وإحالته إلى إحدى الهيئات المتخصصة لتتولى الهيئة عن طريق العضو المقرر المحال إليه المشروع، مفاتحة الوزارات والجهات ذات العلاقة بالمشروع وانتظار واستكمال آراءها، ثم يتولى دراسته وتدقيقه بعد ورود جميع الإجابات من الوزارات مما يؤخذ على المجلس تأخره في انجاز

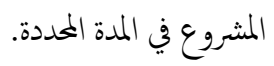

ثالثاً: ورود طلب التدقيق من الوزير المختص أو الرئيس الأعلى للجهة غير المرتبطة بوزارة. حدد قانون مجلس الدولة الأشخاص الذين لم الحق في مخاطبة المجلس والطلب منه تدقيق مشروعات التشريع وهؤلاء الأشخاص هم:

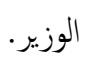

الرئيس الأعلى للجهة غير المرتبطة بالوزارة(32). رابعاً: إرسال مشروع التشريع إلى المدلس مشفوعاً بالأعمال التحضيرية حيث اشترط قانون مجلس الشورى العراقي على الوزارات والجهات غير المرتبطة بوزارة عند الطلب من المجلس تدقيق مشروع أن يرافق بالمشروع أسباب الموجبة وآراء الوزارات أو الجهات ذات العلاقة والأعال التحضيرية في هذا السياق بمحوعة الوثائق التي واكبت التشريع أو سبقته أو قصدت له كالمذكرات

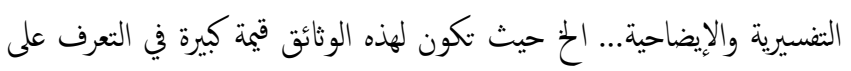
شبه المشرع ليس بالنسبة إلى ما نص عليه التشريع بل أيضاً بالنسبة إلى ما لم ينص عليه بشرط أن لا يؤدي الأمر إلى الخروج عن أحكام القانون أو مخالفة نصوصه(33). 


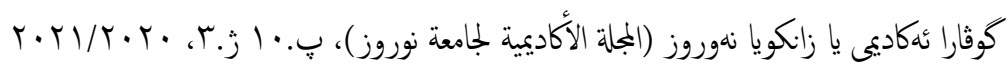

يتضمن هذا النص النعديلات بالإضافة أو النقصان حسب الحالة، أما الشكل الثاني فيكون عبارة عن مذكرة ويكون ذلك في حالة رفض الدولة لمشروع النص المعروض عليه بكامله حيث توضح المذكرة أسباب رفض الجملس لمشروع النص(39). أما عن اشهار مجلس الدولة فتعتبر آراء مجلس الدولة الفرنسي سرية(40). وهو ما يتناسب مع الوظيفة الاستشارية للمجلس كما أن سرية الآراء والمداولات تعطي الحرية لمجلس الدولة لاسيا في الأعال المتعلقة بالجانب السياسي(41). 2.2.3 الفرع الثاني: إجراءات تدقيق مشروعات التشريعات من قبل مجلس الدولة المصري سنتناول في هذا الفرع إجراءات تحتيق مشروعات التشريعات أمام مجلس الدولة المصري، أي الدورة التي تمر بها عملية تدقيق مشروعات التشريعات داخل قسم التشريع التابع لمجلس الدولة الفرني ابتداءً من وصول مشروع التشريع إلى القسم وحتى انتهاء عملية المراجعة وتبليغ الجهة الخختصة بنتيجة المراجعة. هذا وقد بينت اللائحة الداخلية لجلس الدولة هذه الإجراءات والتي تتمثل بما يلي: - - اولاً: يتم إعداد ملف لكل مشروع يرد إلى قسم التشريع تودع به الأوراق ويؤشر على غلاف الملف من الداخل ببيان الأوراق المودعة بأرقام متتابعة

$$
\text { وتاريخ إيداعها وعدد ملحقاتهان(42). }
$$

- ـ ثانياً: يتولى رئيس القسم الإشراف على أعهاله ويوزع العمل على أعضائه ويحدد مواعيد انقاد جلسات القسم كما يعين الجلسة المحددة لنظر المشروع. ويتولى رئس القسم إبلاغ مشروعات التشريعات بصيغتها التي أقرها القسم فور الانتهاء منها إلى الجهات الختصة كما يتولى إبلاغها

$$
\text { بالملاحظات التي ارتآها القسم(43). }
$$

- مالثاً: يبلغ رئس القسم رئيس مجلس الدولة ورئيس الجمعية العمومية والثنتيش الفني وإدارة الفتوى الختصة بالتشريعات التي أتم القسم صياغتها

$$
\text { خلال أسبوع من تاريخ إبلاغها إلى الجهات المختصة(44). }
$$

- - رابعاً: لرئيس وأعضاء القسم الاتصال بالجهات المختصة للحصول على ما يكون لازماً من بيانات وأوراق في المشروعات المحالة إلى القسم ولرئيس القسم أن يطلب بعد العرض على القسم حضور مندوب من هذه الجهات للإدلاء بما يطلب من إيضاحات ويدون ذلك في محضر يعده أحد أعضاء المكتب الفني للقسم تحت إشراف المستشار المقرر ويوقع عليه مندوب
بعد اصدار الرأي آخر إجراء في العملية الاستشارية حيث تسبقه عملية المناقشة التي يتم من خلالها مناقشة التقرير الذي أعده المقرر ومن ثم البت فيه، هذا وتنصب المناقشة على دراسة التقرير أو بالأحرى مشروع النص الذي أعده المقرر والبحث في مكوناته. هذا وتتم المناقشة عادة أما داخل القسم المعني أو داخل الجمعية العامة أو داخل

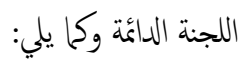
القسم المعني: حيث يمارس القسم المعني داخل مجلس الدولة الفرنسي دوراً هاماً في الوظيفة الاستشارية، ويستجهد ذلك في الآراء التي يقدما القسم حول مشاريع القوانين والأوامر والمراسيم المتعلقة بالإدارة(36). الجمعية العامة: تعد الجمعية العامة لمجلس الدولة الفرنسي أعلى هيئة استشارية في المجلس، وهي تتولى النظر فيما يلي بعد دراسة القسم المختص لها: O مشاريع القوانين ومقترحاتها ومشاريع الأوامر مع مراعاة أحكام المادة (123) (21) من قانون القضاء الإداري. O مشاريع المراسيم الصادرة بموجب المادة (37) من الدستور الفرسي. O ما يحال إليها من الحلات بسبب أهميتها من الوزير المختص أو من نائب الوزير أو رئيس مجلس الدولة الفرن أو رئس أحدى الأقسام

$$
\text { المختصة(37). }
$$

اللجنة الدائمة: استحدثت اللجنة اللائمة لمجلس الدولة الفرنسي عام 1945 وهي تتكون من نائب رئس مجلس الدولة ورئيس أحد الأقسام الإدارية المعينين بموجب أمر من رئيس الوزراء، ويقتصر عمل هذه اللجنة على فضص مشاريع النصوص التي تنطوي على طابع الاستعجال والذي يقرر

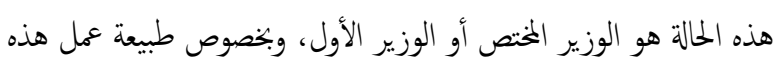
اللجنة، فهي تقوم بالنظر بالتقرير الخاص بالمشروع المراد تدقيقه ومن ثخ تقوم بالتصويت على التقرير النهائي ويكن للجنة الدائمة أن تقرر بعد التحقيق الذي تجريه في القضية إحالة الموضوع إلى المجمية العامة لمناقشته والبت فيه برأي يبلغ إلى الجهة المخطرة(38).

\subsubsection{3 شكل رأي بجلس الدولة واشهاره}

تجدر الإشارة إلى أن الرأي الذي يصدر عن مجلس الدولة يأخذ شكلين، الأول هو عبارة عن مشروع نص يختلف عن مشروع النص المعروض عليه من قبل الحكومة أو البرلمان وهو الشكل الغالب في آراء مجلس الدولة الفرنسي حيث 


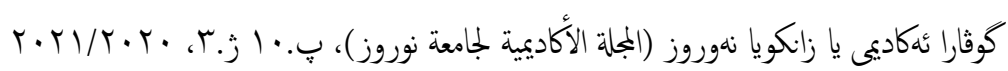

تسجيل مشروعات التشريعات والقضايا التي تحال إلى المجلس في سجل

$$
\text { خاص لدى السكرتير العام للمجلس. }
$$

يتولى السكرتير العام تدقيقه الشروط التي أوجها القانون لقبول المشروع سواء من حيث دخول الموضوع في اختصاص المجلس أو عرضه من الوزير أو رئيس الجهة غير المرتبطة بوزارة ويبين ملاحظاته إلى الرئس. إذا وجدت رئاسة المجلس أن مشروع التشريع ينطوي على نواقص فأن لها أن تطلب من الوزارة أو رئيس الجهة ذات العلاقة استكال تلك النواقص قبل إحالة المشروع إلى المجلس أما إذاكان مشروع التشريع كاملاً فأهها تقرر إحالته إلى أحدى الهيئات المختصة في الجملس أو إلى هيئة خاصة تؤلف

$$
\text { بموافقة رئس مجلس الدولة لغرض دراسته وإبداء الرأي فيه. }
$$

ثانياً: الإجراءات عند إحالة مشروع التشريع إلى أحدى الهيئات المختصة في مجلس

عند إحالة مشروع التشريعات إلى مجلس الدولة العراقي يتم إتباع الإجراءات

يتولى سكرتير الهيئة تسجيله في سجل خاص يمسكه لهذا الغرض قبل أن

$$
\text { يقوم برفع مشروع التشريع إلى رئيس الهيئة. }
$$

يجيل رئيس الهيئة مشروع التشريع مع الأوليات إلى عضو أو أكثر من المستشارين أو المستشارين المساعدين لدراسته وإعداد تقرير عن الموضوع

$$
\text { مع مشروع التشريع. }
$$

يقوم عضو الهيئة الذي أحيل إليه المشروع بدراسته وله ومن أجل استكمال المعلومات المتعلقة بالمشروع أن يطلب حضور مثثل عن الجهة طالبة التشريع أو الجهات ذات العلاقة على أن يكون بدرجة مدير عام على الأقل من أجل سلاع وبحة نظرها، ثم يقوم المقرر بتحرير مخضر يتضمن كل ما تم اتخاذه من إجراءات وما استعع إليه من إيضاحات أو آراء ويعد إلى لى

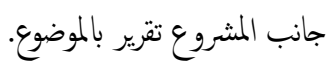

عند انجاز العضو المقرر المشروع يقوم بإرساله إلى سكرتير الهيئة المختصةكي يعرضه على رئيس الهيئة ليتولى رئس الهيئة الثأثير عليه بالعرض إذا كان

$$
\text { مستكملاً لإجراءاته (52). }
$$

- - خامساً: ترسل الدعوة لحضور جلسات القسم مع جدول الأعمال والثقارير المعروضة إلى أعضائه وإلى رئيس إدارة الفتوى المختصة في المشروعات المتعلقة باختصاص إدارته قبل التاريخ المعين لانعقاد الجلسة بأسبوع على الأقل ويجوز عند الاستعجال أو الضرورة إرسال الدعوة وحدها في يوم الانعقاد ذاته وفي حالة قيام مانع لدى رئس إدارة الفنوى يحول بينه وبين حضور الجلسة يخطر رئيس القسم بذلك قبل ميعاد الجلسة بوقت كاف ولا يجوز له أن ينيب عنه أحداً في حضور الجلسة(46). - - سادساً: لا تكون جلسات القسم صحيحة إلا بخضور الأغلبية المطلقة لأعضاء القسم ويبدي كل عضو رأيه فيا يعرض على القسم لأخذ الرأي ويقتصر رأي رئيس إدارة الفتوى الختصة على الموضوعات المتعلقة بإدارته ويبدأ بأخذ رأي أحدث الأعضاء وتصدر القرارات بأغلبية أصوات الحاضرين

$$
\text { وعند التساوي يربح الجانب الذي منه الرئي(47). }
$$

- - مابعاً: للقسم أن يجيل مشروعات القوانين وقرارات رئيس الجمهورية ذات الصفة التثريعية واللوائح ذات الأهمية الخاصة إلى الممعية العمومية لتقرير ما

تراه بشأهي(48) - ت ت - مثأًا: يقوم بمراجعة صياغة التشريعات العاجلة لجنة تشكل من رئيس قسم التشريع أو من يقوم مقامه وأحد مستشاري القسم يندبه رئيسه ورئيس إدارة الفتوى المختصة(49). - - تاسعاً: برسل رئس القسم إلى الثنتيش الفني والأمانة العامة بالبجلس، بياناً إحصائياً شهرياً وآخر سنوياً متضمناً المشروعات التي وردت إلى القسم وما تم إنجازه منها وما أحيل إلى الجمعية العمومية وما لم يتم إنجازه بالقسم وأسباب ذلك(50).

\subsection{3 الفرع الثالث: إجراءات تدقيق مشروعات التشريعات أمام مجلس الدولة} على غرار مجلس الدولة المصري والفرنسي واللذان تم الإثارة إلى الإجراءات المتبعة أمامها بخصوص تدقيق مشروعات التشريعات ثمة إجراءات يتم مراعاتها عند تدقيق مشروعات التشريعات أمام مجلس الدولة العراقي سنشير إليها وكما يلي: أولاً: الإجراءات عند ورود مشروع التشريع إلى مجلس الدولة وتتجسد هذه

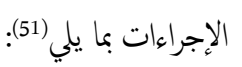


يجناج إلى معايير عدة يجب أن تتوافر فيه بغية تحقيق الغرض منه وملاحظة

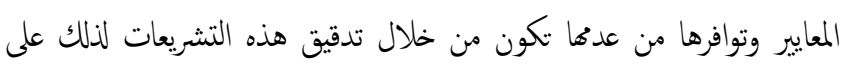
الجهة القائمة بالتدقيق في بجلس الدولة مراعاة هذه المعايبر والتي تتمثل بـ-ـ

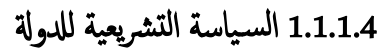

تعرف السياسة التنشريعية بأنها الأداة التي بواسطتها تتم تطبيق السياسة العامة العليا في مجالات مختلفة وهي انعكاس للسياسة العامة العليا(55) أو هي (مسلك أو خطة الجهة الختصة بالتشريع نخو تطبيق السياسة العامة العليا بمجالاتها المتنوعة كالسياسية والاقتصادية والاجتاعية) بذلك فهي تعني التربمة التشريعية للسياسة العامة العليا وللوقوف على المسار الرئيسي لهذه السياسة فأنه يجب

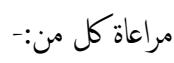
أ. الحقوق والحريات العامة إذ أنه من المعلوم أن أهمية الوثيقة الدستورية تنبع من تحديدها كيفية ممارسة السلطة من قبل القاضين عليها إضافة إلى احتوائها على الحقوق والحريات التي ستتع بها المواطنين، لذلك يستوجب على كل جحة تقوم بتدقيق أي تشريع عادي أو فرعي أن تقوم ابتداءاً ملاحظة عدم اعنداء هذا التشريع (مشروع) على أي نوع أو صنف من الحقوق والحريات وإلا يعتبر هذا المشروع قد ولد مشكلة جديدة، ومن المعلوم أن مفهوم الحقوق والحريات مفهوم واسع وأن الحقوق والحريات يتم تقديما في الدساتير غير ان الحقوق على اهميها تصنف على عدة تصنيفات(56) من حيث أهميتها فهنالك حقوق لا يككن المساس بها مثل حق الحياة، وغيرها يككن تقسيها مثل الحق في التظاهر والحق في التنقل لذلك نستخلص مما سبق أن القوانين يمكن ان تقييد أو تنظيم بعض الحقوق وتضيف من نطاق ممارستها ولكن بهدف حاية المصلحة العامة، غير أن إلغاء هذه الحقوق لا يمكن تقبلها بشكل كامل، لأنه يؤثر على مبداً سيادة القانون حيث ان القانون الذي لا يحترم حقوق وحريات المواطنين لا يحد له طاعة من المواطن والأفراد أنفسهم. ب. سيادة القانون (سيادة القانون تعني أن جميع الأعمال الهيئات العامة والقرارات النهائية تكون غير منتخبة لآثارها القانونية وغير صحية وحتى غير ملزمة للمخاطبين بها، وذلك حتى تكون مطابقة لقواعد القانون العليا التي تخضع لها حيث أنها تكون غير مشروعة متى ما صدرت مخالفة لهذه
تقوم الهيئة بدراسة المشروع وتدقيقه بخضور ممثل الجهة طالبة التشريع والجهات ذات العلاقة بعد تلاوته من العضو المقرر مادة تلو الأخرى وتجرى التدقيقات المتتضية سواء بالتعديل أو التصحيح. ترفع الهيئة الختصة تقريرها مع مشروع التشريع المدقق إلى رئس الجملس ليحيله بدوره إلى الهيئة العامة. يبلغ مثثل الجهة طالبة التشريع والجهات ذات العلاقة بمشروع التشريع بموعد اجتماع الهيئة العامة من قبل سكرتير عام المجلس وبعد أن تناقش الهيئة العامة مشروع التشريع لها أن تقرر أما بإعادة مشروع التشريع إلى الهيئة

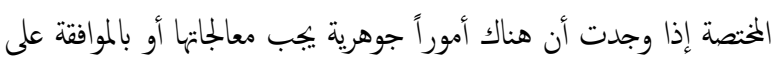
مشروع التشريع أو بالتحفظ عليه كلباً أو جزئيً(53). يرفع مشروع التشريع إلى رئيس بجلس الدولة بعد تدقيقيه من سكرتير عام

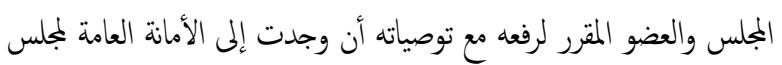
الوزراء ونسخة منه إلى الجهة طالبة التشريع(54).

4. المبحث الثالث: مضمون تدقيق مشروعات التشريعات والزامية عرضها بعد الانتهاء من بحث تعريف التدقيق وشروطها واجراءتها تبين لنا ان الندقيق عملية مكونة من عدة مراحل وعدة اجراءات لذلك لابد من بيان ماهو مضمون الندقيق وعلى ماذا ينصب اضافة المى بيان الزامية عرضه من عدمه وهل هنالك جزاء او اثر مترتب على عدم العرض ، عليه نقسم هذا المبحث الى مطلبين ندرس في الاول مضمون التدقيق وفي الثاني نبحث في الزامية عرض مشروعات

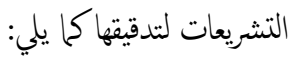

\section{4 المطلب الاول: مضمون تدقيق مشروعات القوانين} لمعرفة مضمون ومحتوى التدقيق الموضوعي لمشروعات القوانين والتي يتم تفعليها من قبل مجلس الدولة يتوجب علينا الوقوف على ركيزتين أساسيتين في هذا الموضوع

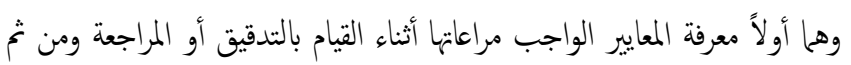
التطرق إلى ما ينصب عله التدقيق وذلك من خلال فرعين كالآتي:

1.1.4 الفرع الأول: المعايير الواجب اتباعها في الثدقيق مشروعات التشريعات قد تختلف مرحلة الندقيق على المراحل السابقة لها كونها أكثز تعمقاً وأكثر شمولية وأوسع مراقبة لأثر التشريعات، ومن المعلوم بأن كل تشريج نابح يعتمد على عدة معايير يعتمد واضعوه ان يكون منسجاً معها بجيث تجعل منه ذو فاعلية وسلياً في التطبيق دون إثارة عراقيل وإظهار عقبات مادية أو قانونية، ولذلك فأن أي تشريع 


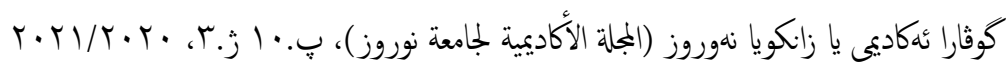

تجديد هذه الحقوق الحريات في جوهرها فأنها تكون غير دستورية، ونخن نرى بان المشرع الدستوري كان موفقاً في هذه المادة بشكل يجعل إلغاء الحقوق والحريات بأنواعها غير وارداً بشكل واقعي حيث أن كل إلغاء يمس جوهر الحق والحرية بينا التقيد والتجديد لا يمسان دائًا جوهر الحق والحرية. أما من يقوم بتحديد هذه السياسة فهو غالباً الشخص الأول في الدولة حيث ان من يمنلك صلاحية اقتزاح القوانين أو التشريعات هو من يختص بالسياسة التشريعية حيث في فرنسا تكون الحكومة وأعضاء البرلمان الحق في اقتراح القوانين في المادة (29)(61) بينا في مصر يكون لرئيس الجمهورية والبرلمان هذه الصلاحية(62)، بينا في العراق فأن المادة 60 تنص على ان (مشروعات القوانين تقدم من رئس الجمهورية وبجلس الوزراء، ثانياً، مقترحات القوانين تقدم من عشرة من أعضاء مجلس النواب أو من أحدى

$$
\text { لجان المتخصصة)(63). }
$$

وعليه نلاحظ ان من يقوم بالسياسة التشريعية هم السياسيون وان من يقومون بالصياغة هم المتخصصون بالقوانين، ولذلك نرى أنه من المهم جداً ان يكون صائن التشريعات على قدر من الإمكانية بحيث يكون بعقدوره ان يترجم السياسة التشريعية إلى قواعد تشريعية اي يستنبط ما يلزم من أدوات لترجة وتجسيد السياسة في قواعد قانونية مصاغة بإتقان تحقق الهدف المرجو من التشريع ومتبع السياسة التشريعية ولا تخلق أي عوائق

جديدة.

\subsubsection{4 المعاهدات والاثفاقيات الدولية}

المعاهدة الدولية هي اتفاق بين شخصين أو أكثر من أشخاص القانون الدولي بهدف أحداث آثار قانونية، وهنالك أنواع من المعاهدات لا مجال هنا لذكرها ولكن ما بال يدخل في نطاق بكثنا هي المعاهدات الشارعة، التي تساهم في تشكيل قواعد القانون الدولي والتي تتطرق إلى المواضيع التي تهم جميع اشخاص القانون الدولي من دول ومنظمات وافراد (64). وبالنسبة لتطبيق قواعد القانون الدولي (الاثفاقيات الدولية) داخل الدولة فان كل دولة اتخذت اتجاهاً بحسب وبهة نظر سياستها التشريعية إلى قواعد القانون الدولي، فنلاحظ ان لا يزال هنالك خلاف حول تحديد أي القانون أسمى (الدولي، والداخلي) غير ان طبيعة الأشخاص القانونية الدولية استقرت على أن
القواعد، ويكون من حق كل ذو مصلحة أن يترافع ضد هذه القوانين بهدف

إلغائها والمطالبة بالتعويض في حالة تعرضه للضرر من جرائها)(57.) ويعود أصل تعريف سيادة القانون إلى الفقيه النمساوي كلزن حيث عرفها بأها (كل دولة ترسم فهيا المعايير القانونية بجيث تكون قوتها محددة)(58). وبذلك نرى بان الدولة عندما تضع قانوناً فأهنا لا تحد فقط من اعال وافعال الأفراد بل أنها تحد من سلطاتها أيضاً بالمقابل وذلك لكونها تحترم عدم الاعتداء على حقوق وحريات الأفراد فيتم تحديد سلطاتها حسب رأي كلزن، وان سيادة القوانين من مقومات الدولة الحديثة وان الحكام والمككومين يفرض عليه التقيد بها حيث أنه المبدأ الأساس لمشروعية لأفعالم، كون سيادة القانون يجقق عدالة القوانين ومشروعيتها ليس كافيًاً وإنما يجب أن يكون كفيلاً وضامناً لمارسة الجميع لحقوقهم وحرياتهم دون اختلاف أو تمييز (59) وان مبدأ سيادة القانون في جوهره هو لا يككن تصوره إلا مع وجود مبدأ الأمن القانوني حيث ان سيادة القانون والأمن القانوني إذا كانت موجودة وتحقق للأفراد شعور الطمائنة بأن التشريعات تضمن حقوقهم حيث ان كلا المبدئين بهدفان إلى تحقيق احترام الحقوق والحريات لجميع الأفراد دون تميز. ونستخلص فيا تقدم ان سيادة القانون تعني وجود قوانين تستمد مشروعيتها من التشريعات الأعلى منها وتتمن قواعد تحترم حقوق الإنسان وتتكفل بجايتها وتضمن ممارسة هذه الحقوق، وهذه الضمانات تتمثل بغطاء مستقل ومحصن(60) وان أي إلغاء أو تقييد لهذه الحقوق أو الحريات تستوجب اصدار قانون يكون مستنداً على الدستور، ولا يغفل علينا أن الدستور العراقي لسنة 2005 قد أورد مبدأ سيادة القانون في المادة (5) رابعاً ذك في المادة 13 الفترة الثانية بعدم جواز سن تشريع متعارض مع الدستور وحتى الرخصة التي اعطيت للأقاليم في سن تثريعات ختنلفة عن

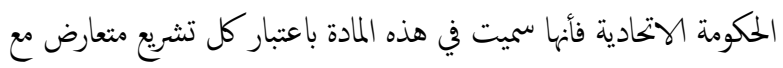
الدستور باطلاً. وذكر في المادة (46) بأنه لا يجوز تقييد الحقوق والحريات الواردة في هذا الدستور إلا وفقاً لقانون أو بناءاً عليها ولكن بشرط أن لا يمس هذا التحديد والتقييد جوهر الحق أو الحرية. ومن كل ما سبق نلاحظ بان أي تشريع يمس الحقوق والحريات ونص على تقيدها أو تحديدها وفقاً للدستور فأنه يكون مشروعاً يتياً إذا تم تقييد أو توري 


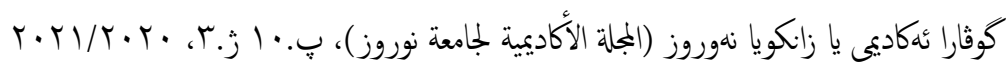

(قرارات المكمة الاتحادية العليا باتة وملزمة للسلطات كافة)(68) أي ان مراعاة هذه القرارات والححكام تكون ملزمة قانوناً كونه يتمتع بالحجية المطلقة لقرارات المككة. ومن الأمثلة الواضحة بهذا الصدد في العراق حيث اصدرت المحكة الاتحادية قراررا(69) بعدم دستورية المادة (59) منه، وبعد ذلك ارسل مشروع تعليات تسهل تنفيذ قانون الأحزاب السياسية رقٍ (36) لسنة 2015 حيث تبين ان المشروع يستند إلى المادة 59 المككى عليها بعدم الدستورية، بذلك امتنعت عن تدقيق المشروع بحجة عدم وجود سند لإصداره أو لان سنده باطلاً. رابعاً: ان الوظيفة الأساسية للقانون هو تنظيم العلاقات في الجمتع، وبعد التطور الذي واكب جميع مجالات الحياة وتزايد متطلبات الأفراد وتدخل الدولة في اكثر لئر الانشطة المتعلقة بصالح الأفراد فتزايد عدد الأظظمة والقوانين التي اصدرتها الدولة وكما بينا ان الهدف تنظيم العلاقات وزيادة عدد التشريعات أدت إلى تشعب القواعد القانونية وتشابك النظام القانوني ووصوله إلى حالات التكرار والتناقض لذلك يستوجب في تدقيق التشريعات مراعاة وحدة التشريع وترتيها بشكل منشق تعبر عن صدورها من لدن مشترك وتعبر عن إرادة مشرع واحد وان صدور التشريعات من إعداد وصياغة وتدقيق من بهة واحدة تكون على نسق واحد متلافي للكثير من العيوب والأخطاء خاصة إذا كانت هذه الجهة بجة مختصة مثل

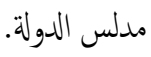

ومن هذا الموضوع نناشد المشرع العراقي والكوردستاني ان يجعل عرض مشروعات التشريعات بشكل إلزاي، لان السلطة التشريعية في إصدارها التشريعات تتأثر بالفراق والاختلافات السياسية، والسلطة التنفيذية عند اصدارها للقوانين والتشريعات الفرعية تتأثر بما هو موجود في الواقع كونها اقرب إل محل تنفيذ القوانين والتعليمات لذلك سوف تكون المواضيع متشابكة ومتعددة وتكون التشريعات متناقضة. فُثلاً عند تدقيق مشروع قانون تعديل قانون العقوبات النافذ في العراق المرقز (111) الصادر سنة (1969) حيث تبين ان القانون الحلالي يعاجج التعديلات المزمع إجرائها لذلك وجد المجلس عدم الحاجة لتثريعه، وأيضًا (70) عندما طلب من مجلس الدولة تدقيق قانون الأخبار عن قيمة الهايا(71) حيث تبين ان الأسباب الموجه لهذا المشروع هو تغطية فعل الموظف عند تلقيه هدايا، وتبين ان هذا الفعل مغطاة بجريمة الرشوة فلا حاجة لإصدار مثل هكذا تشريع وأيضاً قانون انضباط موظفي الدولة(72.). وتلك تعلقها بعدم جدوى اصدار هذا التشريع.
القانون الدولي له علوية على القانون الداخلي وبالتالي يستوجب عدم محالفة لها، أي ان تكون قواعد القانون الداخلي متناسقة مع القانون الدولي. حيث انه من المعلوم ان القانون الداخلي وقواعده يستمد شرعيته من الدستور أو من القواعد التي تكون أعلى منه، لذلك يثور التساؤل ما هي أساس التزام الدول بقواعد القانون الدولي؟ وتحت أي سند تجعل القواعد الدولية نافذة داخل الدولة؟ الجواب هنا ان كل دولة قامت بتعليق القواعد الدولية وفقًا لسياستها الداخلية مع مراعاة وضعها في المجتع الدولي، حيث نرى ان فرنسا اعتبرت المعاهدات الدولية بمثابة القوانين الوطنية في الإلزام وأعلى منها إذا طبقها الطرف الآخر من المعاهدة في دولنه (65) من هنا يتضح ان أي قانون تقوم بتشريعه فرنسا يتوجب الثدقيق فيه كونه غير مخالفاً للقوانين الدولية لان القوانين تتمتع بمرتبة أعلى من مرتبة القوانين لعادية. بينا في مصر فان المثرع اعتبر درجة المعاهدات والاتفاقيات الدولية درجة القوانين العادية، بينما في العراق فقد نصت المادة (61)من الدستور في فقتها الرابعة (تنظيم عملية المصادقة على المعاهدات والاتفاقيات الدولة بقانون يسن بأغلبية ثلثي أعضاء مجلس النواب) اي أنه أيضاً اعطى قوة القانون العادي للمعاهدة الدولية وعليه يستوجب مراعاة جميع المعاهدات والاتفاقيات الدولية والمصادقة عليها والتي اصبحت جزءاً من المنظومة القانونية الداخلية للدولة عن مراجعة وتدقيق

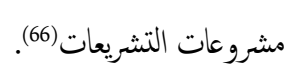

\subsubsection{4 أشار قسم التشريع بمجلس الدولة المصري} في أحدى الفتاوى بان الأحكام الصادرة من المحاكى الدستورية تكون ذا أثر قانوني ومحل اعتبار عند مجلس الدولة اثناء مراجعة مشروعات التشريعات واللوائح وذلك من خلال فتواه رقخ (51) (ان مارسة القسم (قسم التشريع) لاختصاصه بمراجعة وصياغة مشروعات التشريعات التي تعرض عليه وفقاً لأحكام المادة (63) من قانون مجلس الدولة تتطلب منه ان يسترعي النظر إلى الهحكام الصادرة من المحكة الدستورية ذات الصلة بالمشروع، وذلك حتى تجري صياغته وفقاً لهذه الأحكام، وذلك نزولاً على مبداً سيادة القانون والتزاماً بأحكام الدستور ) (67). وهذا يدل على أنه عندما يتم مراجعة أو تدقيق مشروع تثريع يستوجب مراعاة ما صدر عن المحكة الدستورية بخصوص هذا الموضوع ان يؤخذ تلك الأحكام على لى وبجة الالتزام لكونها تتمتع بالصفة الإلزامية حيث نص الدستور العراقي بأن 


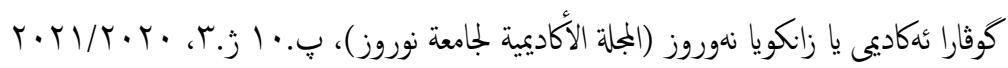

اعداد القوانين بصورة جيدة وعدم الإملام بالقواعد الدستورية ودراستها بتأني وعدم

الإحاطة بأحكام الدستور والمبادئ الأساسية التي ترسيها المحاكي الدستورية(78). وفي العراق أيضاً فان مجلس الدولة أيضاًَ يقوم بتفحص مشروعات القوانين عند تدقيقها بان لا تكون متعارضة مع الدستور ومن الأمثلة التي قام الجملس بإلغاء القواعد القانونية الخالفة للدستور حينا نظر في مشروع قانون الصحة العامة الذي تم إرساله من وزارة الصحة حيث تضمنت المادة 99 البند الخاص على امتناع رك رك

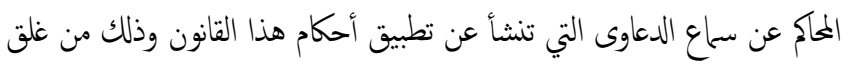
المحلات واتلاف المواد الغذائية أو الطبية بهدف حاية اللحمة العامة، إلا ان المجلس قام بالتوصية بحذف هذه المادة وذلك لأهها جاءت خخالفة لأحكام الدستور حيث تنص المادة (100) منه على ان (يخظر النص في القوانين على تحصين أي

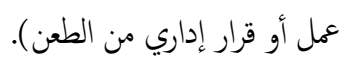

ومن خلال ما سبق يستوجب التنويه إلا ان منح اختصاص مراقبة الشرعية الدستورية ذو أهمية بالغة حيث انها تهدف إلى عدم إصدار قوانين محالفة للدستور وان كانت سوف تتعرض للرقابة اللاحقة على القوانين وذلك بإلغائها إلا ان هذه الرقابة تكون قد بلغت التشريعات محل التنفيذ ومن المؤكد تكون قد انشأت مراكز قانونية وثبتت حقوق والتزامات لذلك فان إلغائها أيضاً قد يثير بعض المشاكل إضافة إلى ان الرقابة الأولى تتولاها هيئة سياسية والرقابة اللاحقة

تتولاها هيئة قضائية. واكد على هذا الرأي الذي نميل إليه وهي ان تكون الرقابة السابقة هي أكثر فعالية وتكون ابتداءاً من مجلس الدولة، إلا أننا لا يكن ان ننفادى عن حقيقة وهي ان القوانين لا يككن التماس جميع أحكاها إلا من خلال التطبيق العملي والاحتكاك بالواقع وهو ما يظهر نقاك التعارض والاختلاف مع احكام ومبادئ الدستور.

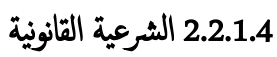

ويقصد بها مراعاة الإجراءات المتبعة في إصدار القوانين علاوة على الاختصاص بإصداره، وذلك من خلال متابعة السند القانوني والاداة القانونية لإصداره ومدى الالتزام بالإجراءات المقرر لإصدار المشروع وعلى النحو الآتي:

السند: وهو ان يكون كل تثريع قد استند على سند في إصداره حيث ان الدستور يعتبر سنداً للقوانين وان القوانين تعتبر سنداً أساسياً في إصدار التشريعات الفرعية وبدون التفويض هذا أو الرخصة لا يكن إصدار التنريعات بلا سند(79). أما حول وجوب وجود هذا التفويض في القانون
2.1.4 الفرع الثاني: ما ينصب عليه تدقيق مشروعات التشريعات

يقوم مجلس الدولة بتدقيق التشريعات الواردة إليه من حيث شرعيتها أي ان تكون مطابقة أو غير مخالفة للقواعد القانونية الأعلى مرتبة، وتكون على نوعين شرعية قانونية وشرعية دستورية نتناولها بشكل منفصل كالآتي:

1.2.1.4 الثرعية الدستورية

ان من أهم واجبات الصائغ ان يتفحص عن التوافق بين التشريعات المكلف بصياغتها وتدقيقها وبين الدستور، وذلك شكلاً وموضوعاً، وذلك كون الدستور يتمنع بالسمو الموضوعي والشكلي، فالأول يقصد به ان لا يصدر تشريعاً يخالف موضوع الدستور ومواده اي لا يجرم فعلاً إباحة الدستور أو يلتمس طريقاً مغايراً لما نص عليه الدستور ، أما الثاني فيعني بطريقة تعديل الدستور المتميزة عن طريقة تعديل التثريعات العادية وهو ما لا يمكن تحتيقه في الدساتير المرنة(73). والشرعية تعني اكتساب الأمر الإطار القانوني سواء كان هذا الأمر إدارياً وسياسياً واجتماعياً (74). فني فرنسا فان مجلس الدولة يتفحص ابتداءاً التشريعات عدم مخالفتها للدستور عند مارسة وظيفته الاستشارية قبل ان يتطرق إلى موضوع مشروع التشريع وملائمته ويستوي في هذه الحالة ان يكون مشروع التشريع محل التدقيق تشريعاً فرعياً أو تشريعياً لقواعد الدستورية بل وحتى احترامه للمبادئ ذات القيمة الدستورية مقل ما ورد في مقدمة دستور 1946 الفرنسي واعلان حقوق الإنسان والمواطن الفرني لسنة 1789(75)، وهذه القدسية منحها المؤسس الدستوري الفرنسي(76)، وبذلك فان مجلس الدولة الفرنسي حينا يدقق في احترام القواعد التشريعية للمشاريع المقدمة إليه لأحمكام الدستور فانه يعتبر ضان قانونية بالنسبة للبرلمان والحكومة بان تلك التشريعات لن يطعن فيها بعدم الدستورية أمام المجلس

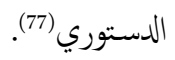
وفي مصر فان مجلس الدولة وعلى غرار ما هو قائم في فرنسا حيث ان أهم ما يقوم به قسم التشريع وأولها هو مراقبة دستورية المشروعات التي تعرض عليه ومراقبة مشروعيها وإيضاح ما يشوبها من خطأ وذلك من خلال بيان النصوص التي تنطوي على خخالفات دستورية وأيضاً اقتاحه للحلول والبدائل التي يمكن من خلالها إزالة الخخالفات تلاك، وتعتبر هذه الوظيفة لمجلس الدولة الوسيلة الأكثر فعالية في مجاهة حالة الارتباك التشريعي السائدة حالياً في مصر وذلك بسبب عدم 


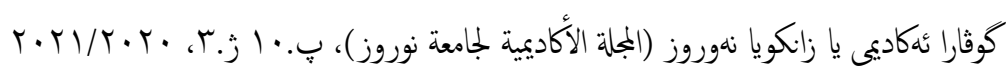

الالتزام بالإجراءات والمراحل المقررة :حيث يقوم الجملس أو الجهة المختصة بالتدقيق بالتحقيق من استيفاء التشريع جميع المراحل والإجراءات المقرة سواء كانت لائحة أو قانوناً أو موافقته في أخذ رأي بجة معينة، فمثلاً في مصر لا يجوز إصدار مصلحة أو تشريع فرعي إلا بعد عرض على مجلس الدولة لذلك فأن ذهب إلى (وجوب أخذ رأي مجلس الشورى في مشروعات القوانين المككلة للدستور طبقاً لأحكام المادة (195) من

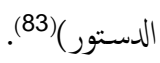
وأيضاً في العراق فأنه تم التوجيه بعدم تشريع مشروع تعليات تسهيل تنفيذ قانون مؤسسة السجناء السياسيين وذلك بحجة عدم أخذ رأي الوزارات والجهات ذات العلاقة أي تم تشريعه بخلاف الإجراءات حيث يستوجب

$$
\text { أخذ آراء والجهات ذات العلاقة(84). }
$$

ومن خلال كل ما سبق من هذا المطلب فأننا نرى أن ججلس الدولة يعتبر حارساً أميناً على النظام القانوني والنسيج التشريعي في الدولة إذا ماكان كل ما يتم إعداده ان يتم عرضه على المجلس لذلك سوف نبحث في القادم

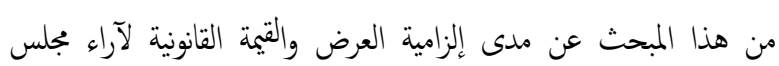

$$
\text { الدولة. }
$$

\section{4 المطلب الثاني: مدى الزامية عرض مشروعات التشريعات على مجلس الدولة}

\section{والاثر المتزتب عليها}

بعدما تطرقنا الى مفهوم تدقيق مشروعات التشريعات ومبادهه وشروطه ومضمونه واهيته بالنسبة للنظام القانوني من خلال ماسبق يتوجب علينا معرفة هل ان عرض مشروعات التشريعات هو وجوبي ام اختياري ؟ واذا كان وجوبيا فا هو الاثر او الجزاء المترتب على عدم العرض ؟ ، مماسبق سوف نقم هذا المطلب الى فرعين نتناول في الوول مدى الزامية عرض مشروعات التشرعات لتدقيقها وفي الثاني الاثر المتزتب على عدم عرضها للندقيق تلك المشروعات كالاتي: 1.2.4 الفرع الأول: مدى إلزامية عرض مشروعات التشريعات على بجلس الدولة لثدقيقها مما يلاحظ على قوانين مجلس الدولة بأهها عادة تنص على أخذ رأي مجلس الدولة سواء كان وجوبياً مثل مصر أو جوازياً مثل العراق غير أنه لميبين إذا عرض على المجلس وأبدى توصياته وآراءه هل هناك جزاء على الجهة التي لم تأخذ بالآراء، والتشريع بذاته هل يكون سلياً والتكييف الذي يمكن وصفه هذا التشريع معيب
نفسه فأنه أثير خلاف حول إمكانية وعدم إمكانية إصدار تشريع فرعي دون وهو التفويض في القانون (التشريعي العادي) وهذا ما تناولناه بالتفصيل في بداية هذا البحث، ومن هذا التبيل عندما أوصى المجلس في العراق بإلغاء مشروع جائزة الثقافة لإبداع الوارد إلى المجلس من قبل وزارة الثقافة، حيث أقر المجلس بأن الوزير له الصلاحية في إصدار تعليمات بهدف تسهيل تنفيذ القانون وليس بهدف استخدام جوائز للمبدعين (80). الأداة القانونية: ويعني ذلك ان يتم إصدار القانون أو المشروع بأداة يمكن

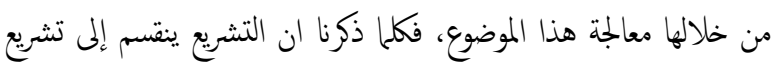
دستوري يتناول الطريقة التي تمارس بها السلطة والحقوق والحريات الأساسية والأحكام ذات الأهمية الكبرى في الدولة وتنظيم سلطانها الرئيسة، وتشريع عادي يقوم بتنظيم الأمور الرئيسية في الحياة والدولة وتشريع فرعي يتضمن التفيلات والجزئيات وانظمة وتعليات، وهذا التسلسل يترتب عليه ان كل صنف منه يقوم بمعالجة مواضيع محددة مستنداً إلى القواعد الأعلى منه وان مراقبة مجلس الدولة عند تدقيقه مشاريع

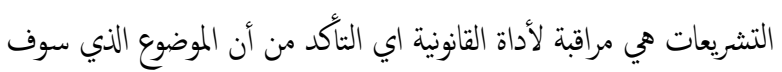
يتناوله التشريع هل بككن ان ينظم بهذا التشريع؟ مثلاً عندما تكون أمام نظام أو مشروع لائحة فيقوم المجلس يتفحص ما إذا كان الموضوع يجوز تنظمه بلائحة أم ينبني ان ينظم بقانون اي تشريع عادي.

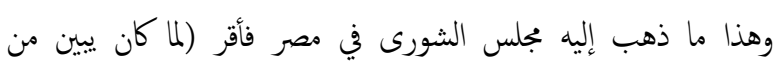
مشروع القرار الجمهوري الماثل للبحث أمام القسم أنه تتضمن بعض الأحكام التي تعتبر استثناء من أحكام المرسوم بقانون رقٌ (178) لسنة 1952 في شأن الإصلاح الزراعي، فأنه يتعين أن تصدر هذه الأحكام وحدها بالأداة التشريعية المناسبة وهي نفس الأداة التي صدرت بها الأحكام المطلوب الخروج عليها - اي بقانون - وبعدئذ ذلك يككن النظر في مراجعة (تحقيق) تقنية الأحكام الواردة في القرار المجهوري المطلوب استصداره بعد ان يكون القانون المشار إليه قد صدر بالفعل)(81). وكذلك مجلس الدولة العراقي عندما قام بتدقيق مشروع تعليمات بيع الأعشاب الذي ورد إليه من وزارة الصحة حيث ان المشروع قد فرض رسوم على منح الإجازة وتجديدها، ولكون المشروع كان تعليات والرسوم يجب ان تفرض بقانون وليس بتعليمات لذا أوصى المجلس بعدم تشريعه(82). 


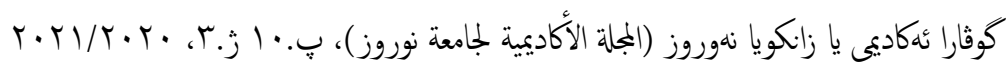

حيث نصت المادة (63) من قانون مجلس الدولة المصري (على كل مصلحة أو

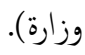
ويكن أخذ رأي مجلس الدولة بشكل اختياري في فرنسا حيث م 23 من الأمر 1945 (يكن أخذ رأي مجلس الدولة إلى الصعوبات التي تظهر في النشاط الإداري) وأيضاً في مصر فان المادة 58 من قانون مجلس الدولة ينص على ان إدارات قسم الفتوى تبدي الرأي في المسائل التي يطلب الرأي فيها من رئاسة الجمهورية ومجلس الوزراء والوزارات والهيئات العامة. والدستور المصري ينص حول مجلس الدولة (بجلس الدولة....) مادة 190. أما في مجلس الدولة العراقي فأنه أقل درجة من المجلس الدولة المصري في إلزام عرش المشروعات لتدقيقها فكيف ان الفرنسي الزها في الدستور والمصري لم يلزما

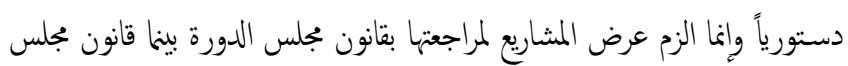
الدولة ففي العراق فأنه لم يرد فيه اي نص يلزم عرض مشروعات القوانين لتدقيقها قبل إصدارها، حيث قد يوجد نوع من الإلزام على شكل توجيهات أو توصيات من بجات عليا بإرسال مشروعات القوانين إلى مجلس الدولة لتدقيقها قبل رفعها إلى لي

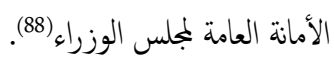
وعليه تنوع بالمشروع العراقي بتدخل دستوري بفرض عرض المشروعات لتدقيقها في مجلس الدولة وأيضاً تعديل قانون مجلس الدولة على غرار قانون مجلس الدولة المصري وذلك بإلزاهم بعرض المشروعات لتدقيقها.

2.1.2.4 موقف الفقه والقضاء من إلزامية عرض مشروعات التشريعات بعدما تطرقنا إلى موقف القانون من إلزامية العرض يفترض بنا ان نسرد موقف الفته والقضاء من إلزامية العرض كونها من مصادر القانون الثانوية، فني فرنسا نلاحظ جانب من الفقه يرى ان استشارة مجلس الدولة الفرنسي تعتبر إلزامية عندما يقرر القانون ضرورة عرض النص التشريعي أو اللائي عليه ويذهب آخرون ان الحكومة تلتزم بأخذ رأي مجلس الدولة تبعاً لما ورد في الدستور في كل مشروع قانون تقوم بإعداده (89). أما في مصر فانتسم الفتهاء إلى قسمين يؤيد العرض على مجلس الدولة هو وجوبي على الإدارة لمراجعتها وهذا الوجوب ملزم فقط على القسم التشريع وبالتالي لايجوز عرض مشروعات القوانين بغية مراجعتها على أي جهة متخصصة أخرى في الوزارات أو مستشاري رئاسة الجمهورية كنها اقسام إدارية تابعة للجهات التي شكلتها، وهذا الرأي الوجوبي يستند إلى المادة 67 من قانون مجلس الدولة وأن
أن سليم؟ لذا سوف نبحث بهذا الصدد في كل من فرنسا والعراق ومصر وموقق الفقه والقضاء فيهم كالآتي:

\subsubsection{4 موقف القانون من إلزامية العرض}

لتحديد موقف التشريعات من هذا العرض ينبني علينا ان ننفحص الدساتير ابتداءاً ومن ثم التطرق إلى التشريع العادي، ففي فرنسا فان الدستور الفرسي سي ستري لسنة 1958(85) قد نص على ان تكون هنالك إلزامية في أخذ رأي مجلس الدولة حيث أن المناقشة في التشريعات تكون بهلس الوزراء بعد أخذ رأي مجلس الدولة، وأشار إليها في أربع حالات وبشكل صرئ 37، 38، 39، 92 وحيث ان المادة 39 تطبق على جميع التشريعات بصرف النظر عن موضوعها أو طبيعها أو إقرارها بصورة مستعجلة(86) والمادة 38 تنص على ان الأوامر التي تقر بناءاً على تفويض برلماني تصدر من مجلس الوزراء بعد أخذ رأي مجلس الدولة. أما المادة 37 ف، من الدستور فأنها تفرض أخذ رأي مجلس الدولة بكل المراسيم التي تعدل النصوص ذات الشكل التشريعي، اي ان المراسيم ذات الشكل التشريعي تلتزم قبل إصدارها بأخذ رأي مجلس الدولة. أما المادة 92 و 38 يقر ان بعرض الأوامر على مجلس الدولة لأخذ رأيه بصورة ملزمة فالمادة 92 أقرت بان (الإجراءات التشريعية اللازمة لإنشاء المؤسسات وحتى تاريخ اذا الإنشاء وتسير المؤسسات العامة تصدر من مجلس الوزراء بعد أخذ رأي مجلس الدولة عن طريق الأوامر التي لها قوة القانون). والمادة 38 أيضاً تقر على ان الأوامر تم إقرارها بناء على تفويض برلماني تصدر من بن بون مجلس الوزراء بعد أخذ رأي مجلس الدولة بشأنها.

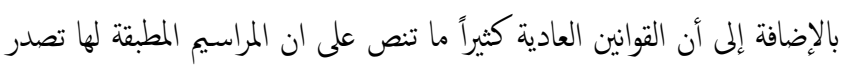
بعد أخذ رأي مجلس الدولة بعد أخذ رأي مجلس الدولة وحتى أنه قد صدر مرسوماً تضمن ان تصدر بعض الإجراءات فانه تطلب رأي مجلي الدولة(87)، ومن كل ما سبق نلاحظ ان أساس عرض مشروعات التشريعات على مجلس الدولة الفرنسي يستند إلى نصوص دستورية وتشريعية وهذا على خلاف ما هو موجود في مصر والعراق وكل بدرجة خاصة. فني مصر نلاحظ فرض نوع من الإلزامية في عرض مشروعات القوانين وأخذ رأي

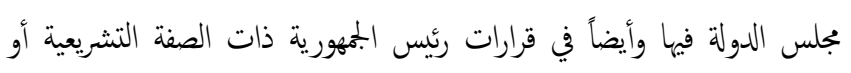
اللوائح، غير ان هذه الإلزامية وردت في قانون مجلس الدولة وليس في الدستور 


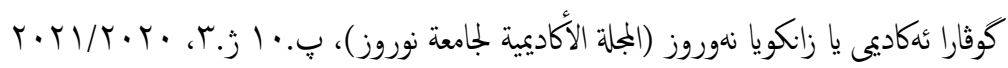

بإرسال المشاريع إلى مجلس الدولة بهدف إعادة النظر في إعدادها وصياغها

وتدقيقها.

\subsubsection{4 موقف القضاء من عرض التشريعات لثدقيقها}

ان موقف القضاء لا يكون غالباً إلا ما اتجه إليه القانون وبما ان الدستور الفرنيي وقوانينه تذهب إلى وجوب عرض مشروعات التشريعات على مجلس الدولة فان

القضاء الفرنسي أيضاً اتخذ هذا المنجج وهو تطبيقاً للقوانين السارية.

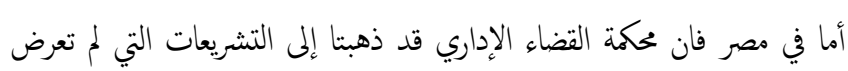
على قسم التشريع بمجلس الدولة المصري أي ان اللوائُ والمراسيم والقرارات التنفيذية للقوانين وفي حالة صدورها قبل عرضها على قسم التشريع لمراجعتها معتبراً إياهاً معيبة في الشكل والإجراءات إلا في حالة الاستعجال القصوى التي يؤدي إلى تقويت الفرصة لا يككن تعويضها(94.9

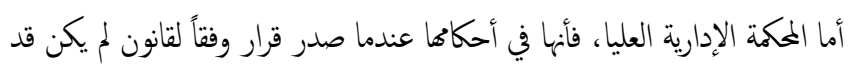
عرض على مجلس الدولة لصياغته صياغة قانونية فطعن امام محكة القضاء الإداري والتي لم تأخذ بهذا السبب ثم طعن بحكم المحكم القضاء الإداري أمام المحكمة الإدارية العليا فأقرت المحكة الإدارية العليا قرارها بأنه لا يتزتب على عدم العرض بطلان القنون اي ان العرض ليس وجوبيًا(95) ولكن كل هذا كان قبل صدور قانون رقّ 47 لسنة 1972 والذي الزم جميع الوزارات بعرضها كما استقر افتاء المجعية العمومية لقسمي الفتوى والتشريع بمجلس الدولة المصري على وجوب عرض برض

$$
\text { مشروعات التشريعات على قسم التشريع بملس الدولة(96). }
$$

أما في العراق فعند تفحص قرارات المحكمة الاتحادية العليا لا يوجد فيها ما يتعلق بالزامية عرض مشروعات التشريعات على مجلس الدولة ولا حتى في المحكة الإدارية العليا ومحاكم القضاء الإداري ولكن قد يوجد بين قرارات مجلس الدولة نسها ما يذهب إلى وجوب عرض مشروع التعليمات على مجلس شورى الدولة

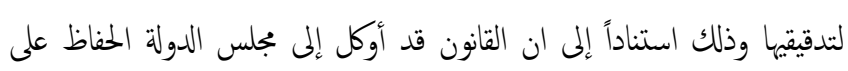
وحدة التشريع وعدم عرض مشروعات التشريعات على مجلس الدولة لتدقيقها

$$
\text { يفوت على التشريع هذه الوحدة(97). }
$$

وبعد ان تطرقنا إلى وجوب العرض من عدمه فهنا نحن لا نسترجي من وجوب لهن عرض هذه المشاريع على مجلس الدولة لكي يكون لمجلس الدولة القرار بسن التشريعات من عدم بل أننا نطلب ان يكون العرض فقط وجوبياً أما الأخذ برأي

المجلس من عدمه فهذا ما سنتناوله في الفرع القادم.
القانون أراد أن يضع الإدارة أمام بجة متخصصة تنذرها بالعيوب الموجودة في المشروع إضافة إلى ان عملية المراجعة من قبل جهة متخصصة مثل قسم التشريع بمجلس الدولة يجعل من التشريعات ان تكون منسقة مع أمال الأمة وتطلعاتها وأن

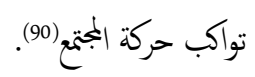
أما القسم الآخر من الفقهاء فذهبوا إلى ان الإدارة ليست ملزمة في عرض مشاريع قوانينها على مجلس الدولة وذلك لان عدم العرض لا يؤثر بحسب اعتقادهم على القيمة القانونية للمشروع ولان كلمة الفصل في سن التشريعات تكون بالتصويت عليها من قبل السلطة التشريعية وتقوم بهذه المهمة (مراجعة التشريعات وتدقيقها) اللجنة التشريعية في مجلس الشعب. ونن نرى بان الرأي الثاني(91) وأن كان صدر رئس اللجنة التشريعية في مجلس الشعب المصري في 2005 ونائب مساعد وزير العدل ورئيس مجلس القضاء الأعلى سابقاً، إلا ان النص في المادة 63 من قانون مجلس الدولة المصري صريخ هو يقبل التأويل على منحى آخر وهو (على كل وزارة أو مصلحة قبل

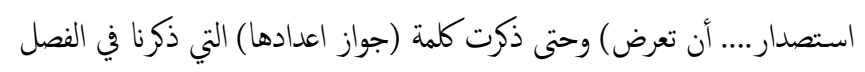
الختص بالإعداد يبين بان العرض وجوبي للمراجعة واختياري للإعداد وهذا ما لمان دعاه أيضاً فتوى من مجلس الدولة المصري في 1998 برقٍ (1131)(92). أما في العراق فان الفقهاء أيضاً انتسموا إلى قسمين قسم يذهب إلى ان هناك وجوب ضمني يمكن استخلاصه من عبارة(93 (ولا يجوز رفعه إلى ديوان الرئاسة مباشرة إلا في الأحوال التي ينسبها الديوان) أي أنه يقيد لزوم التدقيق إلا في الأحوال التي يراها الديوان إضافة إلى وجود مصلحة اجتاعية وقانونية من خلال إلزامية عرض المشروعات للندقيق حيث أنه توجد بمموعة من القوانين كلفت الدولة مبالغ وأعباء ولم تدخل حيز التطبيق بسبب عدم عرضها وتدقيقها من قبل

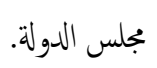
أما الرأي الثاني وهو الأصح بأنه لا يوجد أي نص تشريعي صريح لا في الدستور ولا في التشريعات تجعل من عرض مشروعات التشريعات على مجلس الدولة

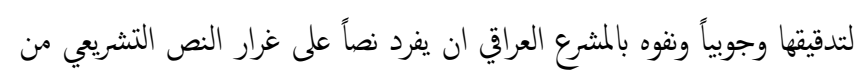
المادة 63 من قانون مجلس الدولة المصري لسنة 1972 (على كل وزارة أو بحة غير مرتبطة بوزارة عرض مشروعات التشريعات على مجلس الدولة بهدف تدقيقها

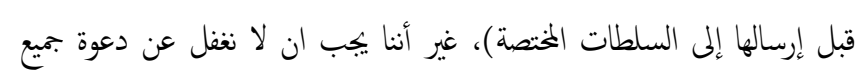
الوزارات والجهات المستقلة وغير المرتبطة بالوزارات ان تشكل عرفاً إدارياً يلزهم 


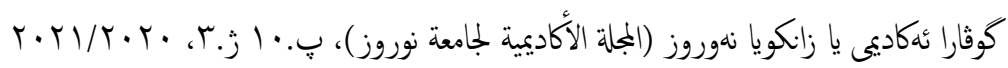

وقد أيد القضاء هذا الموقف بان القانون لا يبطل إذا لم يعرض على مجلس الدولة كما اثرنا إليه، وهذا ماكان له الأثر في اضمحلال اختصاص قسم التشريع بمجلس الدولة(102) بعكس القرارات واللوائُ فقد ايدتها المحكمة في حال اصدار لائحة دون عرض فأها نكون باطلة يعيب الشكل والإجراءات(103) وفي أكثر احكامها تطوراً فقد أقر المحكة الإدارية العليا على بطلان اللوائح والقرارات التي تصدر دون

$$
\text { عرضها على مجلس الدولة:(104). }
$$

ببنها في العراق فان على الرغ من عدم ايجاد نص في الدستور أو قانون مجلس الدولة العراقي يمنع عن تثريع أي قانون دون عرضه على مجلس الدولة وكذلك لم

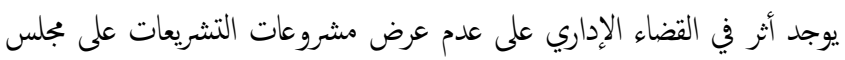
الدولة إلا أننا لاحظنا أنه عدم إرسال المشاريع إلى البملس لتدقيقها لا يجعل منها باطلة وهذا ما اقرته المحكمة الاتحادية العليا في قراراته(105). وعليه ومن خلال كل ما سبق فأننا نرى بأن الأصل لإثبات أثر على عدم العرض هو إلزام العرض في الدستور والقوانين، لأنه طالمال لا يوجد التزام فأنه لا يولد اثراً وهذا الإلزام لا يجب ان يكون فقط على ما تورده الحكومة بل يستوجب العرض على ما تقوم بإعداده المجالس النيابية (البرلمان) ليتم تدقيقه لان العرض لا يعني تدخلاً في سلطة التشريع بل تعني صياغة التشريعات وضبطها ودراسة شرعيتها القانونية والدستورية وعدم معارضتها بذلك يتوجب على المشرع العراقي ان يحذو

$$
\text { حذو المشرع الفرنسي في إلزامية العرض على مجلس الدولة. }
$$

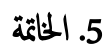

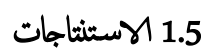

ان عملية مراجعة مشروعات التشريعات يتجلى الهدف أو الغرض الاساسي منها في رفع اي تعارض ريما يكون موجوداً بين احكام القانون المراد إقراره وبين أحكام القواعد القانونية الأخرى الموجودة وفي مقدمتها الدستور فهو (المرجح) ويعتبر بمثابة رقابة استباقية تحول دون اصدار قانون غير دستوري، أو لا يراعي مصاح الدول أو الغايات التي تسعى إلى تحتيقيها، ولماكان الأمر كذلك فأن الأمر يتطلب أن تكون الجهة القائمة بهذه العملية على درجة كيرة بتفاصيل القوانين فضلاً عن توافر المقدرة اللغوية

الأصل لإثبات أثر على عدم العرض هو إلزام العرض في الدستور والقوانين، لأنه طالما لا يوجد التزام فأنه لا يولد اثراً وهذا الإلزام لايجب ان

\subsection{4 الفرع الثاني: أثر عدم عرض مشروعات التشريعات على بجلس الدولة}

لثدقيقها

ان عدم عرض مشروعات التشريعات تناولنا بين وجوب واختيار لكن ما هو الأثر المترتب على عدم عرض المثروعات على مجلس الدولة لتدقيقها فن المعلوم ان عدم العرض لا يترتب عليه آثار إذا كان عرض مشروع التشريع للثدقيق فيه اختيارياً وإنما يتزتب على عدم العرض آثاراً إذا كان العرض على المجلس وجوبياً. ففي فرنسا فأن الدستور الفرسي (98 يذهب إلى أنه أي مشروع معد من قبل الحكومة بشأن التشريعات والأوامر يجب ان يكون محلاً لاستشارة مجلس الدولة وان اي مشروع قانون لم يعرض على المجلس يكون محلاً للطعن بسبب عيب الإجراءات التي يجب ان تتخذ في إعداد القوانين. أما اللوائح فان الإخلال بعدم عرضها فان مجلس الدولة الفرنس قد أقر عند عدم عرض اللائحة عليه تصبح معيبة بعيب عدم الاختصاص وهو من العيوب التي يككن انتشار من تلقاء نفسها دون طعن من صاحب الشأن (99). وبذلك فان المشروعات يجب ان تعرض على مجلس الدولة ولمجلس الدولة ان تبدي آراءها على المشروع وللجهة التي طلبت عرض مشروعها على المجلس أي الحكومة غالباً أما ان تأخذ بآراء مجلس الدولة أو أن لا تأخذ بها وبذلك تكون امام نص غير مشروع وليس لها ان تعدل آراء مجلس الدولة أو تصيف شيئاً لم تكن قد عرضته على المجلس (100).

أما في مصر فان الفقه قد ذهب إلى ان عدم العرض يعتبر عيباً في القانون فان هذا العيب اعتبره البعض بعدم دستورية القانون وهذا لا يككن تصوره لان الوجوب بعرض قد جاء من خلال قانون عادي وهو قانون مجلس الدولة بينا ذهب آخرون إلى وجوب التميز بين مشروعات القوانين ومشروعات اللوائح والقرارات الصادرة عن السلطة التنفيذية. فبالنسبة للقوانين بأنه لا يترتب على عدم عرضها على مجلس الدولة المصري بطلانها وذلك لأننا سبق وان ذكرنا بان هنالك مشاريع تشريعات تعد من قبل مجلس النواب (البرلمان) ولا تمد بمجلس الشعب وتقر وتصبح نافذة ولا يككن لأي بجة ان تقر بطلان هذا القانون إلا المحكة الدستورية وذلك إذا فضت بعدم دستورينه. أما اللوائح فان عرضها على مجلس الدولة مجلس الدولة إجراء جوهري إذا تخلف هذا الإجراء يبطل المشروع أو يلغى(101). 


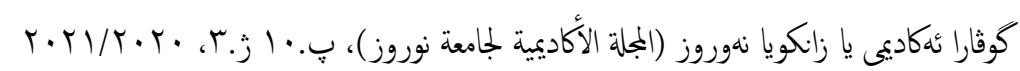

4. د. محمد كال الدين إمام، فن الصياغة التشريعية، دراسة لبعض أحكام الأسرة في ضوء منهجية التقنين، دار الهداية للنشر، المين 1997.

5. د. حسن كيره، الموجز في المدخل للقانون، ط1، منشأة المعارف، الإسكندرية،

.1961

6. علي سعد عمران، القضاء الإدارية، دروس في القضاء الإداري العراقي والمقارن، ط1،

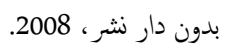

7. مهمود ممحد علي حيره، اعداد وصياغة ومراجعة مشروعات القوانين، بدون دار نشر،

.2015

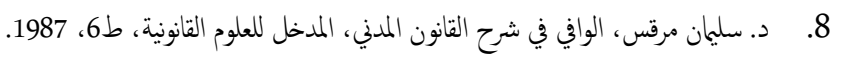

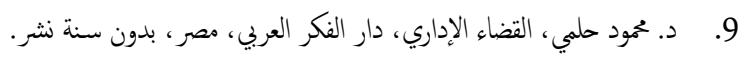

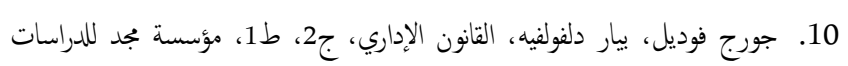
والنشر والتوزيع، بيروت، نئ، 2008.

11. د. مازن ليلو راضي، القانون الإداري، دار المسلة، بغداد، 2017.

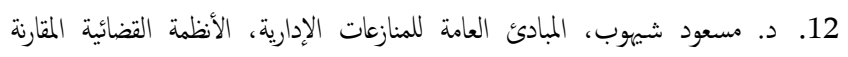

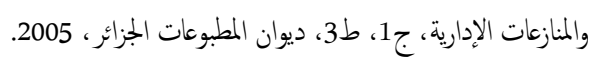

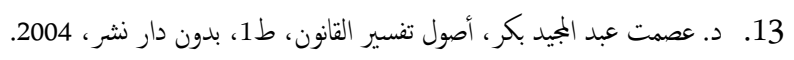

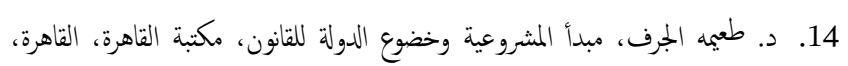

.1963

15. مصطنى أبو زيد فهي، المرافعات الإدارية، (القضاء الإداري وبملس الدولة وقضاء

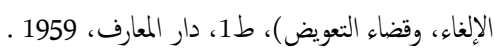

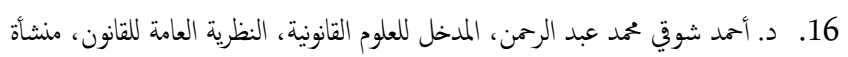

$$
\text { المعارف، الإسكندرية، } 2005 \text {. }
$$

17. د. ساي منقارة، المبادئ الأساسية لحتوق الإنسان وحرياته الأساسية، ط2، المؤسسة

الحديثة للكناب، بيروت،

\section{6}

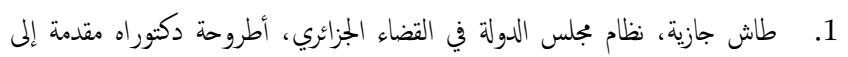

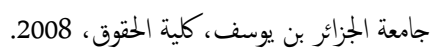

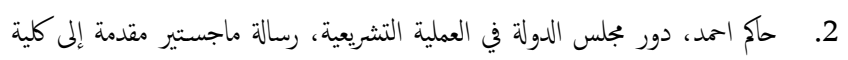
الحقوق والسياسة، جامعة أبي بكر بالقايد، الجزائر، 2016

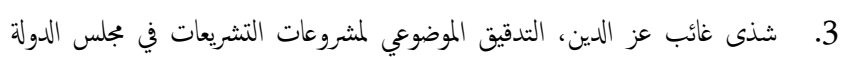

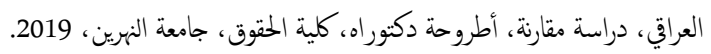

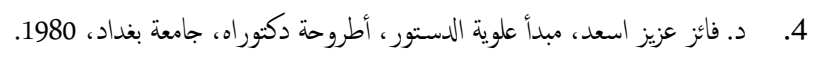

\section{6}

1. د. محمد ماضي، اختصاص مجلس شورى الدولة في صياغة مشروعات الأنظمة

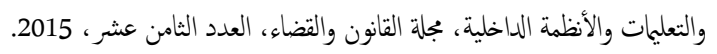

2. فرانسوا لاكراتج، الدور الاستشاري لمجلس الدولة الفرنس، مجلة العدالة، العدد الرابع،

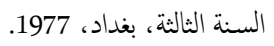

3. سمير محد شحانه، مؤتمر الاتجاهات الحديثة في إعداد وصيانة مشروعات القوانين

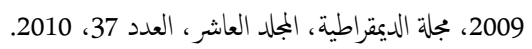

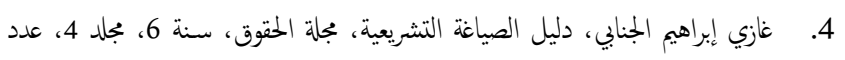

18، سنة 2012،
يكون فقط على ما تورده الحكومة بل يستوجب العرض على ما تقوم

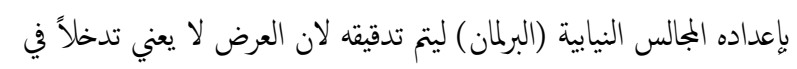
سلطة التثريع بل تعني صياغة التشريعات وضبطها ودراسة شرعيتها القانية والدستورية وعدم معارضتها بذلك يتوجب على المشرع العراقي ان يحذو حذو المثرع الفرنسي في إلزامية العرض على مجلس الدولة. مجلس الدولة يعتبر حارساً أميناً على النظام القانوني والنسيج التشريعي في

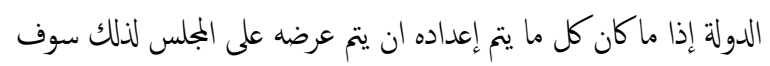
نبحث في القادم من هذا المبحث عن مدى إلزامية العرض والقيمة القانونية لآراء مجلس الدولة.

2.5 المقترحات

ناشد المشرع العراقي والكوردستاني ان يجعل عرض مشروعات التشريعات بشكل إلزاي، لان السلطة التشريعية في إصدارها التشريعات تتأثز بالفراق والاختلافات السياسية، والسلطة التنفيذية عند اصدارها للقوانين والتشريعات الفرعية تتأثز بما هو موجود في الواقع كهنا اقرب إل محل تنفيذ القوانين والتعليمات لذلك سوف تكون المواضيع متشابكة ومتعددة وتكون التشريعات متناقضة.

نتزح منح اختصاص تدقيق ومراقبة تشريعات القوانين الى مجلس الدولة لان الشرعية الدستورية ذو أهمية بالغة حيث انها تهدف إلى عدم إصدار قوانين محالفة للدستور وان كانت سوف تتعرض للرقابة اللاحقة على القوانين وذلك بإلغائها إلا ان هذه الرقابة تكون قد بلغت التشريعات محل التنفيذ ومن المؤكد تكون قد انشأت مراكز قانونية وثبتت حقوق والتزامات لذلك فان إلغائها أيضاً قد يثير بعض المشاكل إضافة إلى ان الرقابة الأولى لى تتولاها هيئة سياسية والرقابة اللاحقة تتولاها هيئة قضائية

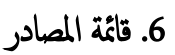

1.6

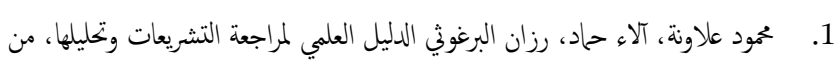

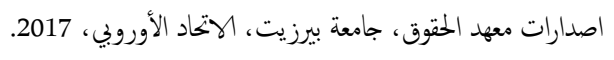

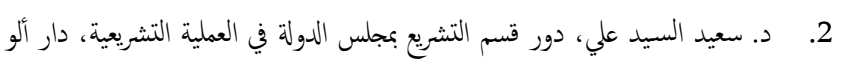

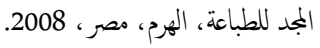

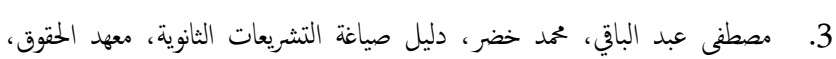
جامعة بيززيت، الاتحاد الأوروبي، 2004 . 


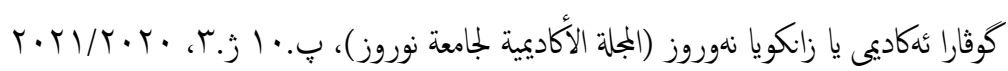

(14) د. محد كمال الدين إمام، فن الصياغة التشريعية، دراسة لبعض أحكام الأسرة في ضوء منهجية التقنين، دار

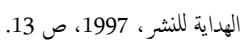

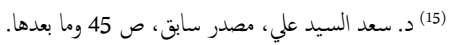

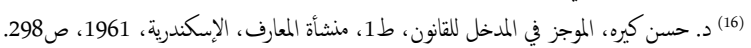

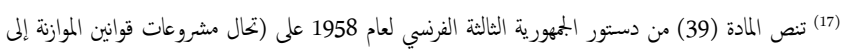
(المجمية الوطنة....). (18) علي سعد عمران، القضاء الإدارية، دروس في القضاء الإداري العراقي والمقارن، ط1، بدون دار نشر، 2008، ص11. (19) شذى غائب عز الدين، التدقيق الموضوعي لمشروعات التشريعات في مجلس الدولة العراقي، دراسة مقارنة،

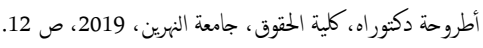

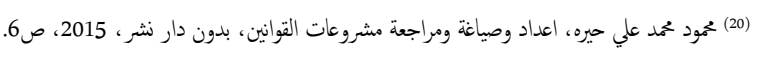

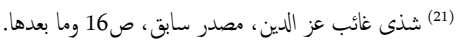

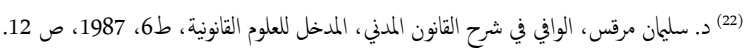

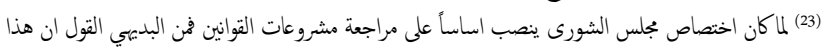

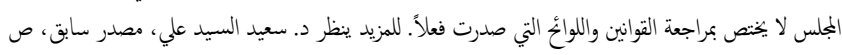
25

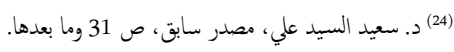

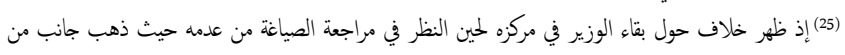

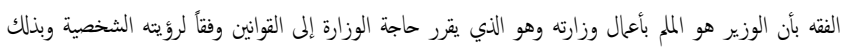

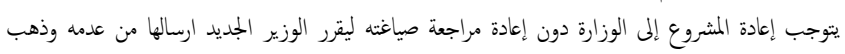

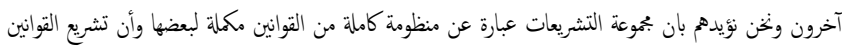

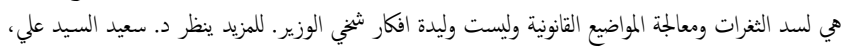

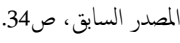
(26) ملف 39/ 2001، مجموعة المبادئ القانونية لقسم التشريع سنة 2000/ 2001 الجزء الثاني، المكتب الفني

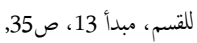

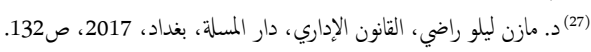

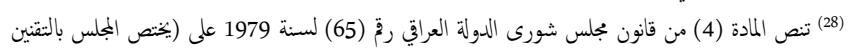

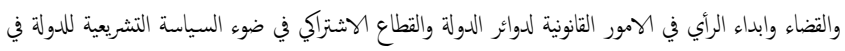
مرحاة البناء الاشتراكي وتكون اعمال الجملس سرية عدا ما ما يتعلق بالقضاء الإدارية).

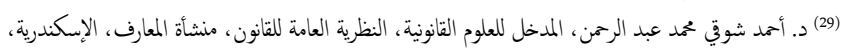
2005، ص77.

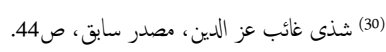

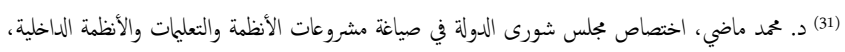

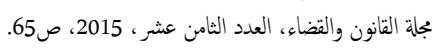

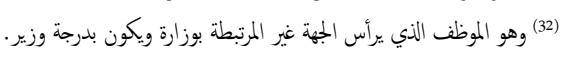

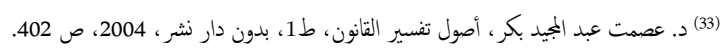

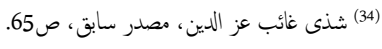

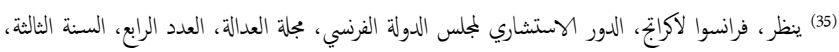

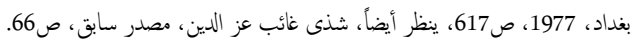

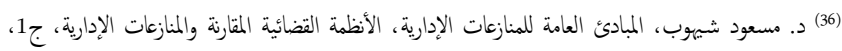

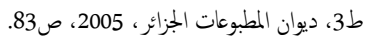

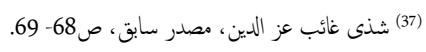

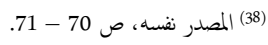

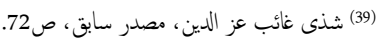

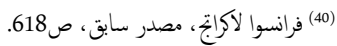

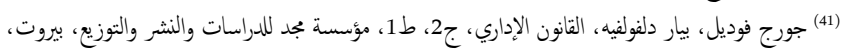

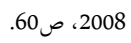

(42) ينظر المادة (103) من اللائحة الداخلية لمجلس الدولة المصري.

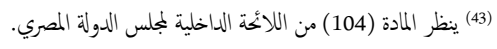

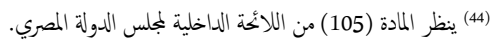

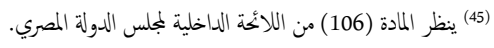

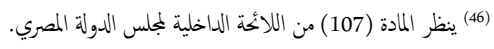
(47) ينظر المادة (108) من اللائحة الداخلية لمجلس الدولة المصري.

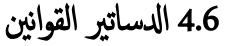

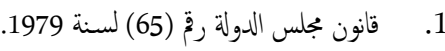

$$
\begin{aligned}
& \text { 2. } \\
& \text { 3. دستور المجهورية المصرية لسنة } 2014 . \\
& \text { 4. دستور العراق الدائم لسنة } 2005 . \\
& \text { 5. قانون انضباط موظفي الدولة القطاع العام رق (14) لسنة } 1991 .
\end{aligned}
$$

$$
\text { 5 } 7 \text { 3. }
$$

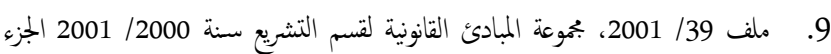

$$
\text { الثاني، المكتب الفني للقسم، مبدأ } 13 \text {. }
$$

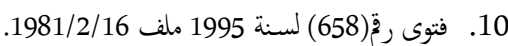

11. قرار المحكة الاتحادية رق 16/اتحادية/2012.

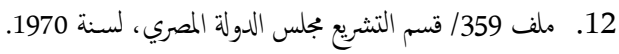

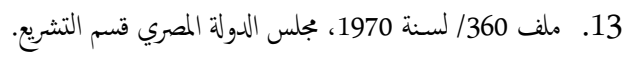

14. ملف 362/ قسم التشريع، لسنة 1970.

7. هوامش 14

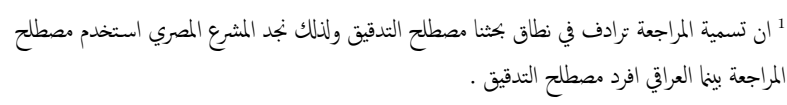

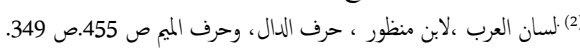

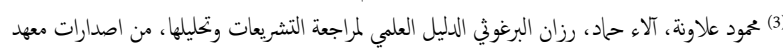

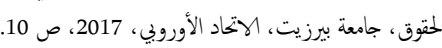

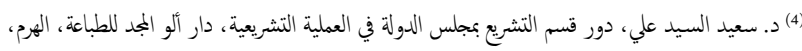
مصر، 2008، ص21. (5 (5 مطنى عبد الباقي، محمد خضر ، دليل صياغة التشريعات الثانوية، معهد الحقوق، جامعة بيززيت، الاتحاد

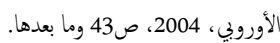

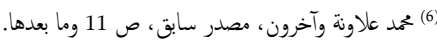

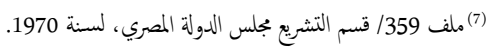

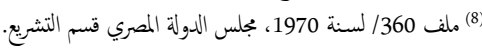

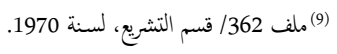

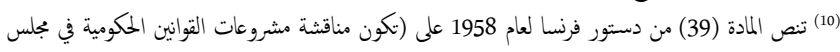

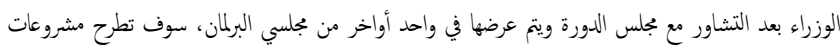

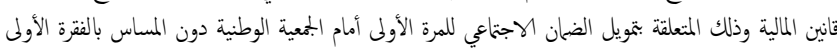

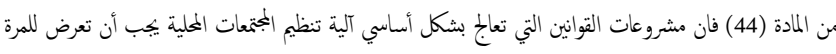
الأولى في مجلس الشيوخ....).

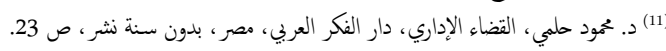

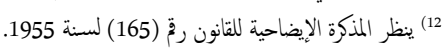

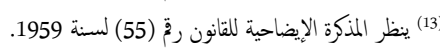




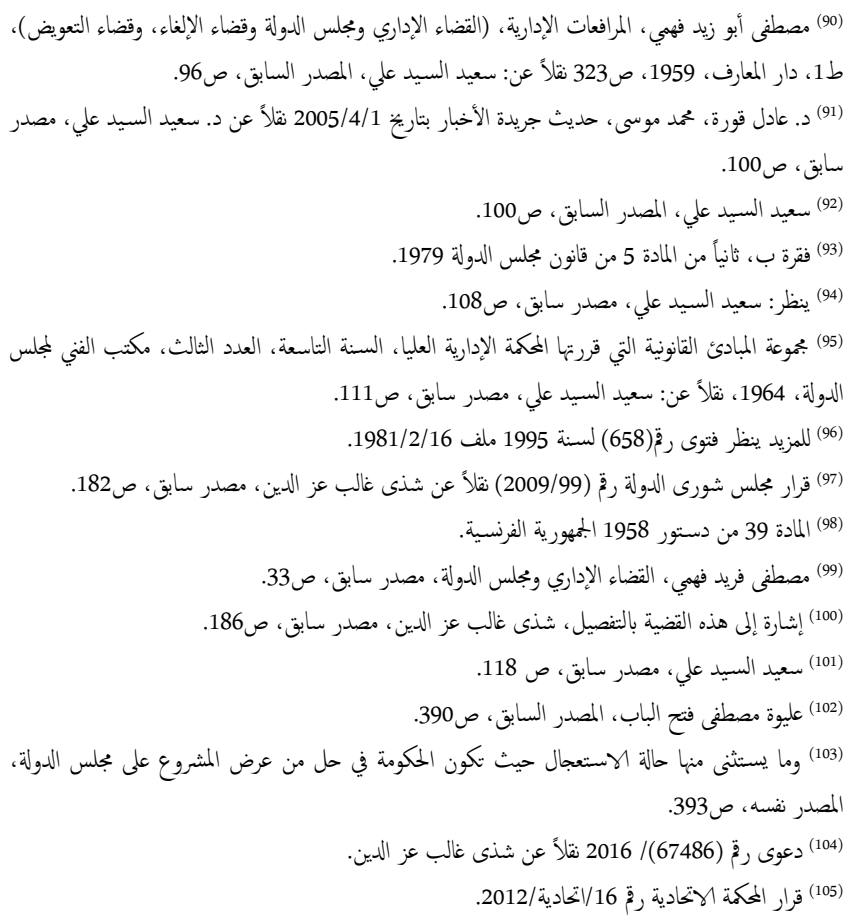

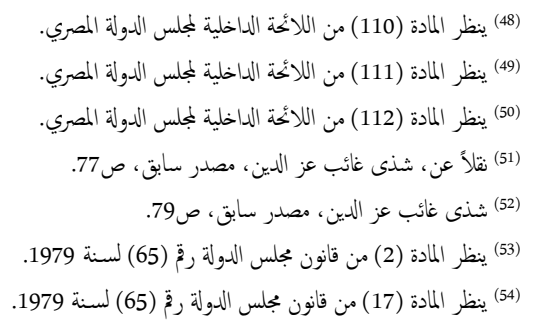

